\title{
Warming and ocean acidification may decrease estuarine dissolved organic carbon export to the ocean
}

\author{
Michelle N. Simone, Kai G. Schulz, Joanne M. Oakes, and Bradley D. Eyre \\ Centre for Coastal Biogeochemistry, Faculty of Science and Engineering, Southern Cross University, Lismore, \\ NSW, 2480, Australia \\ Correspondence: Michelle N. Simone (mnhsimone@gmail.com)
}

Received: 9 September 2020 - Discussion started: 29 September 2020

Revised: 18 January 2021 - Accepted: 19 January 2021 - Published: 16 March 2021

\begin{abstract}
Relative to their surface area, estuaries make a disproportionately large contribution of dissolved organic carbon (DOC) to the global carbon cycle, but it is unknown how this will change under a future climate. As such, the response of DOC fluxes from microbially dominated unvegetated sediments to individual and combined future climate stressors of temperature change (from $\Delta-3$ to $\Delta+5^{\circ} \mathrm{C}$ compared to ambient mean temperatures) and ocean acidification (OA, $\sim 2 \times$ current $\mathrm{CO}_{2}$ partial pressure, $p \mathrm{CO}_{2}$ ) was investigated ex situ. Warming alone increased sediment heterotrophy, resulting in a proportional increase in sediment DOC uptake; sediments became net sinks of DOC ( 3.5 to $8.8 \mathrm{mmol} \mathrm{C} \mathrm{m}^{-2} \mathrm{~d}^{-1}$ ) at warmer temperatures $\left(\Delta+3\right.$ and $\Delta+5^{\circ} \mathrm{C}$, respectively). This temperature response changed under OA conditions, with sediments becoming more autotrophic and a greater sink of DOC (up to $4 \times$ greater than under current $p \mathrm{CO}_{2}$ conditions). This response was attributed to the stimulation of heterotrophic bacteria with the autochthonous production of labile organic matter by microphytobenthos. Extrapolating these results to the global area of unvegetated subtidal estuarine sediments, we find that the future climate of warming $\left(\Delta+3^{\circ} \mathrm{C}\right)$ and OA may decrease estuarine export of DOC by $\sim 80 \%\left(\sim 150 \mathrm{Tg} \mathrm{C} \mathrm{yr}^{-1}\right)$ and have a disproportionately large impact on the global DOC budget.
\end{abstract}

\section{Introduction}

The aquatic dissolved organic carbon (DOC) pool is one of the largest pools of organic carbon on earth (Hedges, 1987), roughly equivalent in size to the atmospheric $\mathrm{CO}_{2}$ reservoir (Siegenthaler and Sarmiento, 1993). The role of
DOC in long-term carbon storage in the ocean has been a focus of research for decades (Siegenthaler and Sarmiento, 1993; Hansell et al., 2009; Bauer and Bianchi, 2011; Wagner et al., 2020), with DOC reaching the ocean interior being effectively stored for millennia (Hansell et al., 2009). Although phytoplankton in the surface ocean are the main source of DOC globally, with an estimated production of around $50 \mathrm{PgC} \mathrm{yr}^{-1}$, only $0.3 \%$ of the DOC they produce reaches the ocean interior (Hansell et al., 2009). Most of the DOC produced by phytoplankton is rapidly remineralized in the water column by heterotrophic bacteria (Azam, 1998). Only more recently has the coastal zone been considered a major source of DOC export to the open ocean and deep sea (Duarte et al., 2005; Maher and Eyre, 2010; Krause-Jensen and Duarte, 2016). The shallow coastal zone accounts for 1 to $10 \%$ of global net primary production (NPP) (Duarte and Cebrián, 1996), with up to $33 \%$ of the associated DOC exported offshore and stored in the ocean interior (KrauseJensen and Duarte, 2016).

Although shallow estuaries and fringing wetlands make up only $\sim 22 \%$ of the world's coastal area (Costanza et al., 1997) and $8.5 \%$ of the total marine area (Costanza et al., 1997), they are quantitatively significant in terms of DOC processing and offshore transport (Smith and Hollibaugh, 1993). In 1998, Bauer and Druffel used radioisotopic carbon $\left({ }^{14} \mathrm{C}\right)$ to identify the source and age of DOC and particulate organic carbon inputs into the open ocean interior. They found that ocean margins accounted for greater organic carbon inputs into the ocean interior than the surface ocean by more than an order of magnitude. Assuming one-third of

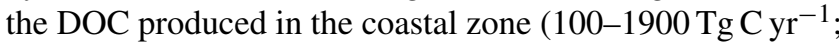
Duarte, 2017) is subducted and reaches the ocean inte- 
rior (Krause-Jensen and Duarte, 2016), 30 to $630 \mathrm{Tg} \mathrm{C} \mathrm{yr}^{-1}$, or up to $3.5 \times$ more DOC, could reach the ocean interior from coastal areas than from the open ocean $\left(180 \mathrm{Tg} \mathrm{C} \mathrm{yr}^{-1}\right.$, Hansell et al., 2009). This is despite coastal areas having a DOC production rate only 0.2 to $3.9 \%$ of that of the open ocean (Duarte, 2017). As such, small changes to the coastal production and export of DOC may have a disproportionate influence on the global DOC budget.

Euphotic estuarine sediments occupy the coastal boundary between terrestrial and marine ecosystems. Microalgal communities (microphytobenthos, or MPBs) are ubiquitous in these sediments, occupying $\sim 40$ to $48 \%$ of the coastal surface area (Gattuso et al., 2020) and generating up to $50 \%$ of total estuarine primary productivity (Heip et al., 1995; MacIntyre et al., 1996; Underwood and Kromkamp, 1999). MPBs exude some of the carbon they fix as extracellular substances, including carbohydrates (Oakes et al., 2010), and can therefore be a source of relatively labile DOC in net-autotrophic sediments (Cook et al., 2004; Oakes and Eyre, 2014; Maher and Eyre, 2010). The dominant sink of DOC in estuarine sediments, however, is uptake by heterotrophic bacteria (Azam, 1998). These heterotrophic bacteria not only consume autochthonous DOC from upstream (Boto et al., 1989), but their biomass is influenced by the lability of sediment organic matter (OM) (Hardison et al., 2013), which can be altered by MPB production (Hardison et al., 2013; Cook et al., 2007). Estuarine sediments are therefore a potentially important sink for DOC.

Unvegetated estuarine sediments can affect the quantity and quality of DOC input to the ocean by (1) acting as a source of autochthonous DOC, through MPB production (Duarte, 2017; Krause-Jensen and Duarte, 2016; Maher and Eyre, 2010), or (2) modifying allochthonous and terrigenous DOC inputs (Fichot and Benner, 2014). Through efficient mineralization of DOC (Opsahl and Benner, 1997), estuaries can act as a sink for DOC and a source of $\mathrm{CO}_{2}$ to the ocean (Frankignoulle et al., 1998; Fichot and Benner, 2014; Sandberg et al., 2004). Given the disproportionate contribution of estuaries to the export of DOC to offshore marine ecosystems, relative to their surface area, it is important to understand how this balance of DOC sources and sinks within estuaries may change with future shifts in climate, particularly expected increases in temperature and ocean acidification $(\mathrm{OA})$ associated with elevated atmospheric $\mathrm{CO}_{2}$ concentrations.

Climate projection models assuming a high-emission scenario suggest that atmospheric $\mathrm{CO}_{2}$ concentrations could more than double by the end of the century, increasing the partial pressure of $\mathrm{CO}_{2}\left(p \mathrm{CO}_{2}\right)$ in surface waters to $1000 \mu$ atm and decreasing $\mathrm{pH}$ by 0.3 units, together termed OA (RCP8.5; IPCC, 2019). There is also expected to be an increase in mean surface ocean temperature by $2-4{ }^{\circ} \mathrm{C}$ (RCP8.5; IPCC, 2019) and increased frequency of unseasonably warm days (Morak et al., 2013; Fischer and Knutti, 2015).
Primary producers fix dissolved inorganic carbon (DIC) during photosynthesis and release DOC directly through exudation and/or indirectly when they are grazed upon. Photosynthetically produced DOC is the main source of DOC in the ocean (Hansell et al., 2009) and fuels local microbial mineralization (Azam, 1998). Heterotrophic bacteria within estuarine sediments respire the carbon from DOC as $\mathrm{CO}_{2}$, which can then be recaptured by photoautotrophs (Riekenberg et al., 2018), closing the microbial loop (Azam, 1998). DOC or DIC that is not captured is ultimately effluxed to the overlying water column and may be transported from estuaries to the coastal ocean. Individually, increased temperature and $\mathrm{CO}_{2}$ have been reported to enhance primary productivity and DOC production in Arctic (Czerny et al., 2013) and temperate phytoplankton communities (Wohlers et al., 2009; Engel et al., 2011; Liu et al., 2017; Novak et al., 2018; Taucher et al., 2012), and in temperate stream sediments (Duan and Kaushal, 2013). However, one study in a temperate fjord reported no enhancement of DOC production despite $\mathrm{CO}_{2}$-enhanced phytoplankton productivity (Schulz et al., 2017). This uncertainty of the response to individual climate stressors is exacerbated when considering how the combination of OA and warming will affect DOC processing. To date, only one study has considered this combined stressor effect on DOC (Sett et al., 2018), observing no difference in DOC production by temperate phytoplankton relative to current conditions under the combined stressors (Sett et al., 2018).

To understand the potential effect of future climate on DOC fluxes, it is essential that both individual and combined effects of $\mathrm{OA}$ and warming are considered. Here we focus on changes in DOC fluxes in unvegetated estuarine sediments, as these systems have the potential for significant uptake of DOC that is currently exported to the coastal ocean. In this study, benthic DOC responses in unvegetated estuarine sediments were investigated over an $8^{\circ} \mathrm{C}$ temperature range under both current and projected future high- $p \mathrm{CO}_{2}$ conditions in an ex situ laboratory incubation.

We expected that warming would promote a stronger heterotrophic than autotrophic microbial response in shallow euphotic sediments (Patching and Rose, 1970; VázquezDomínguez et al., 2012; Yang et al., 2016) and, as such, there would likely be more DOC remineralization (Lønborg et al., 2018) than "new" DOC production by photoautotrophs (Wohlers et al., 2009; Engel et al., 2011; Novak et al., 2018). Moreover, despite the potential stimulation of primary productivity in unvegetated muddy sediments by OA (Vopel et al., 2018), or more likely high $p \mathrm{CO}_{2}$, and potential enhancement of DOC production (Engel et al., 2013; Liu et al., 2017), this increase in labile DOC may promote bacterial productivity and DOC mineralization (Hardison et al., 2013). In addition, increased DOC availability alone may increase heterotrophic bacterial biomass production and activity (Engel et al., 2013). We therefore predicted that increases in DOC production from $\mathrm{OA}$ alone or in combination with warming 
may be counteracted by increased consumer activity, potentially diminishing the available DOC pool under future climate conditions.

\section{Methods}

\subsection{Study site}

A subtidal site $(\sim 1.5 \mathrm{~m}$ below mean sea level) in the subtropical Clarence River estuary, Australia, was used for this study $\left(29^{\circ} 24.21^{\prime} \mathrm{S}, 153^{\circ} 19.44^{\prime} \mathrm{E}\right.$; Fig. 1). Sediment at the site was unvegetated and characterized as euphotic cohesive sandy mud (31-36\% of grains within $250-500 \mu \mathrm{m}, 61-$ $65 \%$ within $63-250 \mu \mathrm{m}$, and $\sim 2 \%<63 \mu \mathrm{m}$; Lewis and McConchie, 1994). Temperature $\pm 0.3{ }^{\circ} \mathrm{C}, \mathrm{pH} \pm 0.5$ units, and salinity $( \pm<1 \%)$ were measured over $24 \mathrm{~h}$ using a Hydrolab HL7 submerged at the site. The tidal cycle introduced a salinity range of $10-35, \mathrm{pH}$ range of 7.92-8.15 units (min-max), and mean daily temperature of $23.9 \pm 1.6^{\circ} \mathrm{C}\left(20-25^{\circ} \mathrm{C}\right)$. The surface sediments $(0-2 \mathrm{~cm})$ had a porosity of 0.43 and an organic matter content of $\sim 3.5 \%$ (of dry weight), determined from mass loss after combustion $\left(490^{\circ} \mathrm{C}\right)$ of dried sediment $\left(60^{\circ} \mathrm{C}\right)$ (Luczak et al., 1997). The Clarence River estuary has low nutrient loading (Eyre and Pont, 2003) with dissolved inorganic nitrogen (DIN) concentrations $<2 \mu \mathrm{M}$ (Eyre, 2000). This is consistent with concentrations determined at the time of this study $(\sim 0.9-1.9 \mu \mathrm{M}$ DIN, Supplement Sect. S4).

\subsection{Core collection}

Sediment $(\sim 20 \mathrm{~cm}$ depth) was collected and capped in acrylic cores $(9 \mathrm{~cm}$ diameter $\times 47 \mathrm{~cm}$ length) allowing for $\sim 1.8 \mathrm{~L}$ of overlying water on 9 and 16 January 2018 ( 15 and 12 cores, respectively). Thalassinidean shrimp, Trypaea australiensis, burrows were avoided and therefore excluded from the collected cores as their occasional inclusion would result in considerable variability in sediment processes (Webb and Eyre, 2004) that would mask potential treatment effects. To ensure sediments were subtidal, cores were collected during low tide. Immediately after core collection, $\sim 700 \mathrm{~L}$ of site water was also collected to fill a laboratory incubation setup.

\subsection{Incubation setup}

Within $6 \mathrm{~h}$ of core collection, all cores were in the laboratory, submerged and uncapped in site water. The cores were placed in one of four temperature tanks - control $\left(23^{\circ} \mathrm{C}\right), \Delta-3^{\circ} \mathrm{C}$ $\left(20^{\circ} \mathrm{C}\right), \Delta+3^{\circ} \mathrm{C}\left(25^{\circ} \mathrm{C}\right)$, and $\Delta+5^{\circ} \mathrm{C}\left(28^{\circ} \mathrm{C}\right)-$ filled with $\sim 80 \mathrm{~L}$ of site water, with temperatures maintained and monitored via thermo-regulating aquarium pumps. Each tank had three cores $(n=3)$.

The ex situ study design allowed control of temperature, $p \mathrm{CO}_{2}$, and light that would be difficult to achieve in situ. Due to limited space, this investigation was conducted over 2 weeks with two complementary incubations repeated back to back. The incubation in the first week (912 January 2018) had cores in the four temperature tanks subjected to high $p \mathrm{CO}_{2}(\sim 1000 \mu \mathrm{atm})$, achieved with a $\mathrm{CO}_{2}$-enriched airstream (initially adjusted and set when attached to a LICOR LI-7000) bubbled into tank water via airstones and air pumps. The incubation in the second week (16-20 January 2018) maintained current $p \mathrm{CO}_{2}$ conditions $(\sim 450 \mu \mathrm{atm})$ by circulating ambient laboratory air through the tank water via airstones and air pumps. An additional tank was included in week 1 alongside the high- $p \mathrm{CO}_{2}$ incubation. This tank was a control tank equivalent to the control tank present week 2, allowing for comparison of the two separate incubations (see Table 1 for details). The temperature and $p \mathrm{CO}_{2}$ manipulations were within 12 and $4 \%$, respectively, of their in situ ranges (see Sect. 2.1) to reduce any potential shock effect for the sediment community.

Water columns within cores were stirred at $\sim 60 \mathrm{rpm}$ throughout the incubations via magnetic stir bars $(\sim 5 \mathrm{~cm}$ above sediment surface) interacting with an external rotating magnet, ensuring water columns were well mixed whilst avoiding sediment disturbance (Ferguson et al., 2003, 2004). High-pressure sodium lamps ( $400 \mathrm{~W}$; Philips Son-T Argo 400 ) were used to simulate mean daytime field conditions, providing $\sim 270-280 \mu \mathrm{mol}$ quanta $\mathrm{m}^{-2} \mathrm{~s}^{-1}$ of photosynthetically active radiation at the water surface of the tanks. Lamps were turned on in the mornings in line with natural diel light cycling, following a similar in situ $\sim 12 \mathrm{~h}$ dark-12 h light cycle. Cores were pre-incubated at treatment conditions for 36$48 \mathrm{~h}$, before solute-flux incubations. This pre-incubation period would be sufficient for three to six generations of the dominant microbial members of unvegetated estuarine sediments, diatoms, and cyanobacteria (Mori et al., 1996; Greene et al., 1992), allowing time for the microbial community to acclimatize to the new treatment conditions.

\subsubsection{Solute-flux incubation}

Immediately after pre-incubation, cores were capped for a $20 \mathrm{~h}$ (10 h dark, $10 \mathrm{~h}$ light) solute-flux incubation to measure rates of $\mathrm{O}_{2}$, DIC, and DOC production and consumption over a diel cycle. To adhere to natural diel cycling, cores were capped at dusk to start the incubation on a dark cycle. Samples were collected from three cores per tank at each of three time points in the diel cycle (dark start (dusk), dark end and light start (dawn), and light end (dusk)). Water was collected and syringe-filtered to determine concentrations of DIC $(0.45 \mu \mathrm{m}$ Minisart filter, $100 \mathrm{~mL}$ serum bottle; without headspace, poisoned with $50 \mu \mathrm{L}$ of saturated $\mathrm{HgCl}_{2}$, stored at room temperature) and DOC (GF/F filter, $40 \mathrm{~mL}$ glass vial with silicon septum; without headspace, poisoned with $20 \mu \mathrm{L}$ of $\mathrm{HgCl}_{2}$, injected with $200 \mu \mathrm{L}$ of $85 \% \mathrm{H}_{3} \mathrm{PO}_{4}$, stored at room temperature). As water was removed for sampling, it was replaced with gravity-fed water maintained in a collapsible bag under the same atmospheric conditions and temperature. After all cores were sampled, dissolved oxygen (DO) 

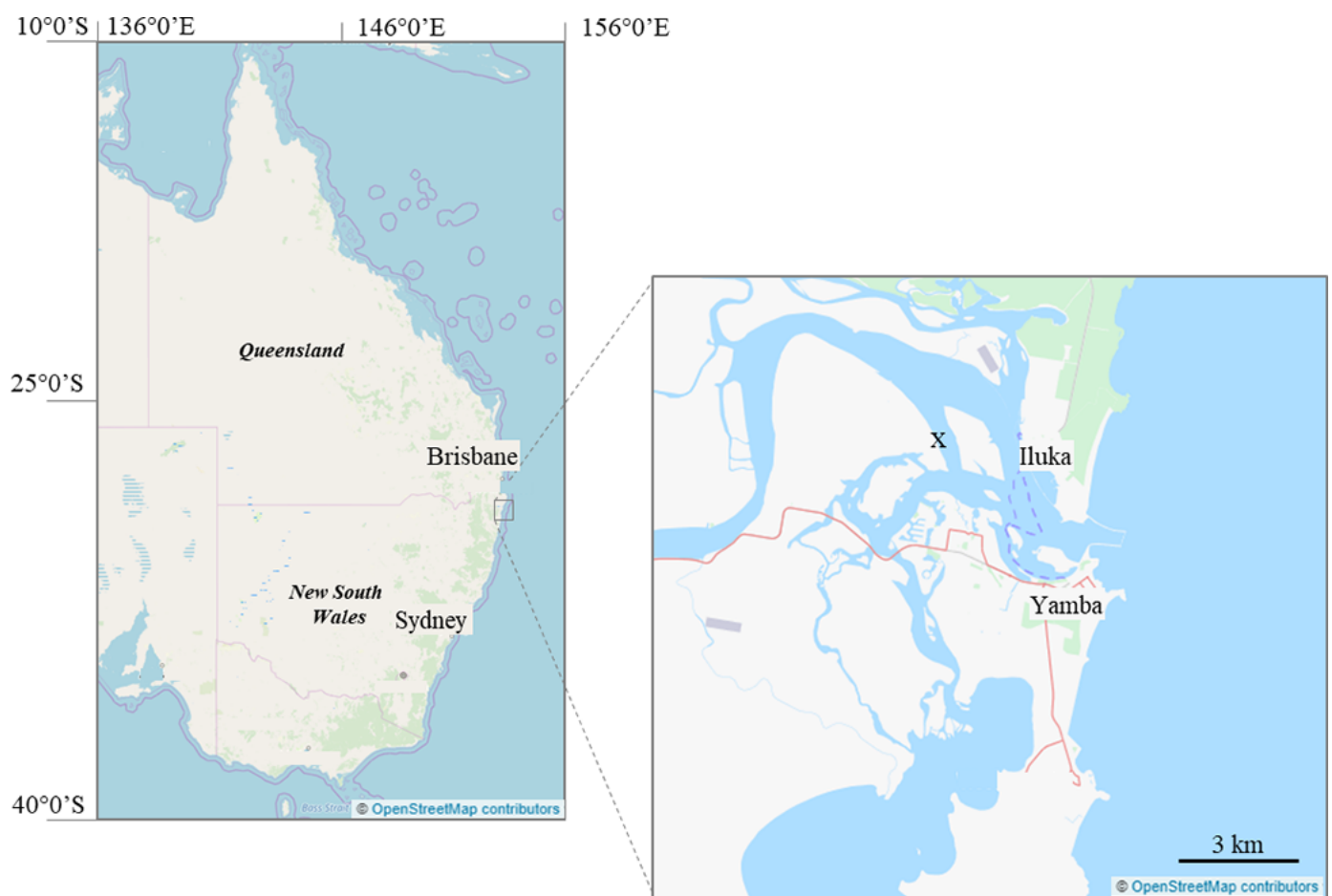

Figure 1. Study location (x; $\left.29^{\circ} 24.21^{\prime} \mathrm{S}, 153^{\circ} 19.44^{\prime} \mathrm{E}\right)$ marked on a map of Yamba, NSW, embedded in an east coast map of Australia. (C) OpenStreetMap contributors 2020. Distributed under a Creative Commons BY-SA License.

Table 1. Start conditions for incubations at current and high $p \mathrm{CO}_{2}$ levels $\left(^{*}\right)$ showing mean $( \pm \mathrm{SD})$ of various carbonate parameters. $\mathrm{CON}^{*}$ is the overlapping control core present in the high- $p \mathrm{CO}_{2}$ incubation week.

\begin{tabular}{|c|c|c|c|c|c|c|c|c|}
\hline Scenario & $\begin{array}{r}\text { Sal } \\
(\% o)\end{array}$ & $\begin{array}{r}T \\
\left({ }^{\circ} \mathrm{C}\right)\end{array}$ & $\begin{array}{r}\mathrm{pH} \\
\text { (free scale) }\end{array}$ & $\begin{array}{l}p \mathrm{CO}_{2} \\
(\mu \mathrm{atm})\end{array}$ & $\begin{array}{r}\mathrm{HCO}_{3}^{-} \\
\left(\mu \mathrm{mol} \mathrm{kgSW}{ }^{-1}\right)\end{array}$ & $\begin{array}{r}\mathrm{CO}_{3}^{2-} \\
\left(\mu \mathrm{mol} \mathrm{kgSW}{ }^{-1}\right)\end{array}$ & $\begin{array}{r}\text { TA } \\
\left(\mu \mathrm{mol} \mathrm{kgSW}{ }^{-1}\right)\end{array}$ & $\begin{array}{r}\text { DIC } \\
\left(\mu \mathrm{mol} \mathrm{kgSW}{ }^{-1}\right)\end{array}$ \\
\hline$\Delta-3{ }^{\circ} \mathrm{C}$ & 24.4 & $\begin{array}{r}21.0 \\
( \pm 0.1)\end{array}$ & $\begin{array}{r}8.08 \\
( \pm 0.02)\end{array}$ & $\begin{array}{r}453.1 \\
( \pm 24.0)\end{array}$ & $\begin{array}{l}1750.8 \\
( \pm 2.9)\end{array}$ & $\begin{array}{r}123.9 \\
( \pm 6.4)\end{array}$ & $\begin{array}{r}2048.7 \\
( \pm 12.6)\end{array}$ & $\begin{array}{l}1889.8 \\
( \pm 3.3)\end{array}$ \\
\hline$*$ & 17.7 & $\begin{array}{r}20.8 \\
( \pm 0.1)\end{array}$ & $\begin{array}{r}7.60 \\
( \pm 0.02)\end{array}$ & $\begin{array}{r}989.8 \\
( \pm 40.7)\end{array}$ & $\begin{array}{l}1232.9 \\
( \pm 2.6)\end{array}$ & $\begin{array}{r}24.28 \\
( \pm 0.9)\end{array}$ & $\begin{array}{l}1293.8 \\
( \pm 2.8)\end{array}$ & $\begin{array}{l}1291.6 \\
( \pm 2.9)\end{array}$ \\
\hline Control & 24.4 & $\begin{array}{r}23.1 \\
( \pm 0.0)\end{array}$ & $\begin{array}{r}8.07 \\
( \pm 0.02)\end{array}$ & $\begin{array}{r}469.9 \\
( \pm 27.2)\end{array}$ & $\begin{array}{l}1744.7 \\
( \pm 4.1)\end{array}$ & $\begin{array}{r}130.2 \\
( \pm 6.9)\end{array}$ & $\begin{array}{r}2056.9 \\
( \pm 12.1)\end{array}$ & $\begin{array}{l}1889.6 \\
( \pm 2.0)\end{array}$ \\
\hline$*$ & 17.7 & $\begin{array}{r}23.2 \\
( \pm 0.1)\end{array}$ & $\begin{array}{r}7.63 \\
( \pm 0.06)\end{array}$ & $\begin{array}{r}995.9 \\
( \pm 146.6)\end{array}$ & $\begin{array}{l}1281.6 \\
( \pm 5.5)\end{array}$ & $\begin{array}{r}29.5 \\
( \pm 4.3)\end{array}$ & $\begin{array}{r}1354.7 \\
( \pm 12.7)\end{array}$ & $\begin{array}{l}1343.4 \\
( \pm 6.1)\end{array}$ \\
\hline$\Delta+3{ }^{\circ} \mathrm{C}$ & 24.4 & $\begin{array}{r}25.6 \\
( \pm 0.5)\end{array}$ & $\begin{array}{r}8.08 \\
( \pm 0.01)\end{array}$ & $\begin{array}{r}471.5 \\
( \pm 13.3)\end{array}$ & $\begin{array}{l}1723.5 \\
( \pm 2.0)\end{array}$ & $\begin{array}{r}136.9 \\
( \pm 3.4)\end{array}$ & $\begin{array}{l}2051.6 \\
( \pm 6.2)\end{array}$ & $\begin{array}{l}1874.5 \\
( \pm 1.5)\end{array}$ \\
\hline$*$ & 17.7 & $\begin{array}{r}25.8 \\
( \pm 0.2)\end{array}$ & $\begin{array}{r}7.64 \\
( \pm 0.12)\end{array}$ & $\begin{array}{r}1011.1 \\
( \pm 248.6)\end{array}$ & $\begin{array}{l}1265.8 \\
( \pm 2.7)\end{array}$ & $\begin{array}{r}32.7 \\
( \pm 9.3)\end{array}$ & $\begin{array}{r}1346.7 \\
( \pm 23.6)\end{array}$ & $\begin{array}{l}1329.2 \\
( \pm 3.4)\end{array}$ \\
\hline$\Delta+5{ }^{\circ} \mathrm{C}$ & 24.4 & $\begin{array}{r}27.1 \\
( \pm 0.1)\end{array}$ & $\begin{array}{r}8.11 \\
( \pm 0.05)\end{array}$ & $\begin{array}{r}445.2 \\
( \pm 56.2)\end{array}$ & $\begin{array}{r}1698.3 \\
( \pm 22.7)\end{array}$ & $\begin{array}{r}155.3 \\
( \pm 17.0)\end{array}$ & $\begin{array}{r}2069.3 \\
( \pm 17.6)\end{array}$ & $\begin{array}{l}1866.1 \\
( \pm 7.4)\end{array}$ \\
\hline$*$ & 17.7 & $\begin{array}{r}27.9 \\
( \pm 0.1)\end{array}$ & $\begin{array}{r}7.65 \\
( \pm 0.12)\end{array}$ & $\begin{array}{r}989.6 \\
( \pm 40.7)\end{array}$ & $\begin{array}{l}1254.4 \\
( \pm 5.2)\end{array}$ & $\begin{array}{r}34.3 \\
( \pm 1.3)\end{array}$ & $\begin{array}{l}1339.2 \\
( \pm 3.8)\end{array}$ & $\begin{array}{l}1317.1 \\
( \pm 5.2)\end{array}$ \\
\hline $\mathrm{CON}^{*}$ & 17.7 & $\begin{array}{r}23.3 \\
( \pm 0.1)\end{array}$ & $\begin{array}{r}7.96 \\
( \pm 0.05)\end{array}$ & $\begin{array}{r}431.9 \\
( \pm 45.7)\end{array}$ & $\begin{array}{l}1193.0 \\
( \pm 4.1)\end{array}$ & $\begin{array}{r}58.4 \\
( \pm 6.1)\end{array}$ & $\begin{array}{r}1338.2 \\
( \pm 10.9)\end{array}$ & $\begin{array}{l}1265.5 \\
( \pm 1.1)\end{array}$ \\
\hline
\end{tabular}


concentrations, temperature, and $\mathrm{pH}$ were measured using a high-precision Hach HQ40d multiprobe meter with an LDO probe and $\mathrm{pH}$ probe, calibrated to 3-point NIST buffer scale $\left(R^{2}=0.99\right)$. Probes were inserted into a resealable port fitted in each lid, ensuring no incubation water exchanged with tank water. After the dawn sampling, lamps were switched on.

DIC concentrations were determined with an AIRICA system (MARIANDA, Kiel, Germany) via infrared absorption using a LICOR LI-7000 and corrected for accuracy against certified reference material, batch no. 171 (Dickson, 2010). Measurements on four analytical replicates of $1.5 \mathrm{~mL}$ sample volume were used to calculate DIC concentration as the mean of the last three out of four measurements (typical overall uncertainty, $<1.5 \mu \mathrm{mol} \mathrm{kg}{ }^{-1}$ ). DIC and $\mathrm{pH}$ measurements were then used to calculate the remaining carbonate chemistry parameters (Table 1) using $\mathrm{CO}_{2} \mathrm{SYS}$ (Pierrot et al., 2006). Total borate concentrations (Uppström, 1974) and boric acid (Dickson, 1990) and stoichiometric equilibrium constants for carbonic acid from Mehrbach et al. (1973), as refit by Dickson and Millero (1987), were used. Comparison of $\mathrm{pH}$ (free scale) measured with a Hach HQ40d multiprobe meter and $\mathrm{pH}$ calculated from measured total alkalinity and DIC (Table S1) indicated an uncertainty for potentiometric $\mathrm{pH}$ measurements of $\pm 0.05 \mathrm{pH}$ units. Propagating the uncertainty in $\mathrm{pH}$ measurements with the uncertainty of DIC measurements translates to a $p \mathrm{CO}_{2}$ uncertainty of $\pm \sim 110$ and $\sim 56 \mu$ atm under high- $p \mathrm{CO}_{2}$ and current conditions, respectively. This uncertainty is well within the treatment variability measured among cores (Table 1) and is therefore considered unlikely to have contributed substantially to differences in treatment response. DOC concentrations were measured via continuous-flow wet oxidation using an Aurora $1030 \mathrm{~W}$ total organic carbon analyser (Oakes et al., 2011) (uncertainty of $\sim 3 \%$ ).

\subsection{Data analysis}

The dissolved oxygen and DIC measurements were used to estimate benthic microalgal production inside the cores. Net primary production and respiration (NPP and $R$, $\mu \mathrm{mol} \mathrm{O} \mathrm{m}^{-2} \mathrm{~h}^{-1}$ ) were defined as the light and dark cycle oxygen evolution, respectively, where DIC and DOC light and dark fluxes $\left(\mu \mathrm{mol} \mathrm{C} \mathrm{m}^{-2} \mathrm{~h}^{-1}\right)$ were defined using the evolution of DIC and DOC concentrations, respectively. Fluxes (NPP, $R$, DIC, or DOC) were calculated as

flux $=\frac{(\text { end }- \text { start }) \times V}{(T \times A)}$,

where end and start are the dissolved oxygen, inorganic carbon, or organic carbon concentrations $\left(\mu \mathrm{mol} \mathrm{O} \mathrm{L}^{-1}\right.$ or $\mu \mathrm{mol} \mathrm{CL^{-1 }}$ ) at the end and start of the light or dark cycle, $V$ is the water column volume $(L), T$ is hours of incubation, and $A$ is surface area of the core.
Gross primary productivity (GPP, $\mu \mathrm{mol} \mathrm{O} \mathrm{m}^{-2} \mathrm{~h}^{-1}$ ) was calculated using NPP and $R$, as follows:

$\mathrm{GPP}=-R+\mathrm{NPP}$.

The production-to-respiration ratio $(P / R)$ was calculated using GPP and $R$ scaled for a $12 \mathrm{~h}$ light $-12 \mathrm{~h}$ dark diel cycle (Eyre et al., 2011).

$P / R=\frac{(\mathrm{GPP}) \times 12 \mathrm{~h}}{(-R \times 24 \mathrm{~h})}$

Finally, net fluxes for DIC and DOC were calculated from the dark and light fluxes from Eq. (1) and presented as mmol $\mathrm{C} \mathrm{m}^{-2} \mathrm{~d}^{-1}$ for a $12 \mathrm{~h}$ light-12 $\mathrm{h}$ dark diel cycle.

Net flux $=(($ darkflux $\times 12 \mathrm{~h})+($ light flux $\times 12 \mathrm{~h})) / 1000$

Temperature sensitivity coefficients ( $Q_{10}$ values) were used to evaluate the temperature dependence of metabolic rates on temperature increases of $10^{\circ} \mathrm{C}$. This was expressed simply as an exponential function:

$Q_{10}=\left(\frac{R_{2}}{R_{1}}\right)^{10^{\circ} \mathrm{C} /\left(T_{\mathrm{opt}}-T_{1}\right)}$,

where $R_{1}$ and $R_{2}$ are the $R$, NPP, or GPP rates measured at temperatures of $20^{\circ} \mathrm{C}\left(T_{1}\right)$ and optimal temperatures $\left(T_{\mathrm{opt}}\right)$, where rates are highest, respectively.

\subsubsection{Scaling rates}

Rates in the overlapping control cores each week were checked to ensure comparability between incubations. If means $( \pm \mathrm{SD})$ were significantly different (did not overlap), rates from individual treatment cores were scaled to the overall mean control rate of both weeks $(n=6)$. This was done by calculating the relative proportion of treatment rates (tProp., $\mu \mathrm{mol} \mathrm{N} \mathrm{m}{ }^{-2} \mathrm{~h}^{-1}$ ) to the control rates present in its week (Eq. 6),

tProp. $=\frac{\text { tRate }}{\text { control }}$

where tRate is the individual core rate, and control is the mean rate of control cores present during the incubation $(n=3)$. This proportional rate was then multiplied by the overall control mean rates (averaged across both weeks, $n=6$ ) to scale individual core rates and calculate comparable treatment means $(n=3)$ across incubations (see Sect. 3.1 for details on scaled rates).

\subsection{Statistical analysis}

Homogeneity of variances (Levene's test) was tested before analysis to minimize the potential for type I error. All tests were run in MATLAB (Mathworks, 2011) with significance defined at a maximum alpha of $<0.05$. Where Levene's test returned a significant result, either datasets were log-transformed or else, if negative values were present, an alpha of 0.01 was used for the subsequent analyses of variance (ANOVAs). 


\subsubsection{Net variability with temperature and $\mathrm{CO}_{2}$}

Net fluxes were compared among treatments to identify the individual and combined effects of temperature and $p \mathrm{CO}_{2}$ on $\mathrm{O}_{2}$, DIC, and DOC fluxes. To investigate the effect of increased $p \mathrm{CO}_{2}$ alone, data from control temperature cores at both current and high $p \mathrm{CO}_{2}$ levels $(n=2)$ were compared using a one-way ANOVA. A two-way ANOVA on each dataset identified whether there were interacting effects on $\mathrm{O}_{2}$, DIC, and DOC fluxes of temperature $(n=4)$ and $p \mathrm{CO}_{2}$ $(n=2)$. Finally, one-way ANOVAs were also run for each $p \mathrm{CO}_{2}$ level to investigate differences in sediment responses across temperatures $(n=4)$. Post hoc Tukey's tests were then used to determine which temperatures had similar or different responses.

\subsubsection{Diel variability with temperature for DIC and DOC fluxes}

Differences between dark and light cycles were compared to further investigate changes observed in DIC and DOC net variability. Similar analyses to those described above were applied. To examine differences among temperatures $(n=4)$, light condition $(n=2)$, and whether light condition significantly interacted with temperature response, two-way ANOVAs were applied to current- and high- $p \mathrm{CO}_{2}$ cores, separately. Following this, each light condition was further investigated to consider the individual temperature responses in the light and dark separately using one-way ANOVAs and post hoc Tukey's tests.

\section{Results}

\subsection{Overlapping control scaling}

Mean rates calculated from overlapping control cores present in each week were compared to establish whether the two sets of incubations were directly comparable, and whether changes attributed to high $p \mathrm{CO}_{2}$ levels were truly due to that treatment, not just a temporal shift in how the sediments were behaving. The $P / R$ ratios were similar for incubations $(0.84 \pm 0.01$ and $0.83 \pm 0.04$, Table S2); however, the magnitude of the $R$ and NPP fluxes was $\sim 23 \%$ greater for control cores in the high- $p \mathrm{CO}_{2}$ week (Table S2; discussed in Sect. $4.0)$. As such, $R$ and NPP rates of cores were scaled to mean control rates $(n=6)$ using the proportional rate difference calculated between the treatments and the individual controls present in the respective weeks $(n=3)$ (Eq. 6). Scaled rates were within $\pm 13 \%$ of actual rates. There were no significant differences between controls for light or dark production of DIC or DOC.

\subsection{Productivity and respiration responses to $\mathrm{OA}$}

High- $p \mathrm{CO}_{2}$ conditions alone (at mean ambient temperatures, $23^{\circ} \mathrm{C}$ ) significantly increased $P / R$ by $\sim 20 \%$ over control ratios (one-way interaction: $F_{3,4}=101.9, p=0.0005$; Fig. 2d). This was a result of significant increases in NPP ( $\sim 42 \%)$ compared to control conditions (one-way interaction: $F_{3,4}=241.4, p<0.0005$; Fig. $2 b$ ), in concert with no significant change in $R$ (one-way interaction: $F_{3,4}=4.5$, $p=0.10$; Fig. 2a). Insignificant increases of DIC uptake in the light reflected the significant increases in NPP under high- $p \mathrm{CO}_{2}$ conditions at ambient temperature (one-way interaction: $F_{3,4}=5.9, p=0.07$; Fig. $3 \mathrm{c}$ ). Like $R$, DIC in the dark did not change with $p \mathrm{CO}_{2}$ (one-way interaction: $F_{3,4}=1.3, p=0.33$; Fig. $3 b$ ). GPP also significantly increased under high- $p \mathrm{CO}_{2}$ conditions at ambient temperatures (one-way interaction: $F_{3,4}=65.3, p=0.001$; Fig. 2 c), with net DIC significantly shifting from a slight efflux to a slight influx (one-way interaction: $F_{3,4}=24.3, p=0.008$; Fig. 3a).

\subsection{Productivity and respiration responses to temperature and $\mathrm{OA}$}

Temperature had a strong effect on $R, \mathrm{NPP}$, GPP, and $P / R$, whereas only light cycle NPP and, in turn, GPP and $P / R$ were affected by OA.

The response of $R$ to temperature was similar at both current and high $p \mathrm{CO}_{2}$ levels (no two-way interaction: $F_{3,16}=0.77, p=0.53$; Fig. 2a), and it was not affected by $p \mathrm{CO}_{2}\left(\mathrm{CO}_{2}\right.$ effect, two-way interaction: $F_{1,16}=0.99$, $p=0.34$; Fig. 2a). Accordingly, $Q_{10}$ values for $R$ were similar for current (1.66) and high- $p \mathrm{CO}_{2}$ (1.69) conditions (Table 2). $R$ changed significantly across the $8{ }^{\circ} \mathrm{C}$ temperature range, increasing by $\sim 11$ and $\sim 29 \%$ in higher-temperature cores $\left(\Delta+3\right.$ and $\Delta+5^{\circ} \mathrm{C}$, respectively) and decreasing by $\sim 16 \%$ in $\Delta-3^{\circ} \mathrm{C}$ cores (temperature effect, two-way interaction: $F_{3,16}=36.93, p<0.0001$; Fig. $2 a$ ).

Sediment NPP was significantly affected by the interaction of $p \mathrm{CO}_{2}$ and temperature (two-way interaction: $F_{3,16}=8.92, p=0.001$; Fig. 2 b). Under current $p \mathrm{CO}_{2}$ conditions, NPP decreased significantly with increased temperature (one-way interaction: $F_{3,8}=41.94, p<0.0001$; Fig. 2b), shifting from net autotrophy in the light in lowand control temperature cores (efflux of $590 \pm 121$ and $613 \pm 10 \mu \mathrm{mol} \mathrm{O}_{2} \mathrm{~m}^{-2} \mathrm{~h}^{-1}$, respectively) to net heterotrophy in higher-temperature cores (influx of $163 \pm 228$ and $390 \pm 97 \mu \mathrm{mol} \mathrm{O}_{2} \mathrm{~m}^{-2} \mathrm{~h}^{-1}$ for $\Delta+3$ and $\Delta+5^{\circ} \mathrm{C}$, respectively). Warming alone therefore resulted in a reduction in NPP by $126 \%$ at $\Delta+3{ }^{\circ} \mathrm{C}$ and $164 \%$ at $\Delta+5^{\circ} \mathrm{C}$, compared to the control (Fig. 2a). OA in general significantly increased NPP rates over those measured under current $p \mathrm{CO}_{2}$ conditions $\left(\mathrm{CO}_{2}\right.$ effect, two-way interaction: $F_{1,16}=21.92$, $p=0.0003$; Fig. 2b), and $Q_{10}$ of NPP increased from 1.13 to 1.92 when OA was present (Table 2). As such, under 
(a)
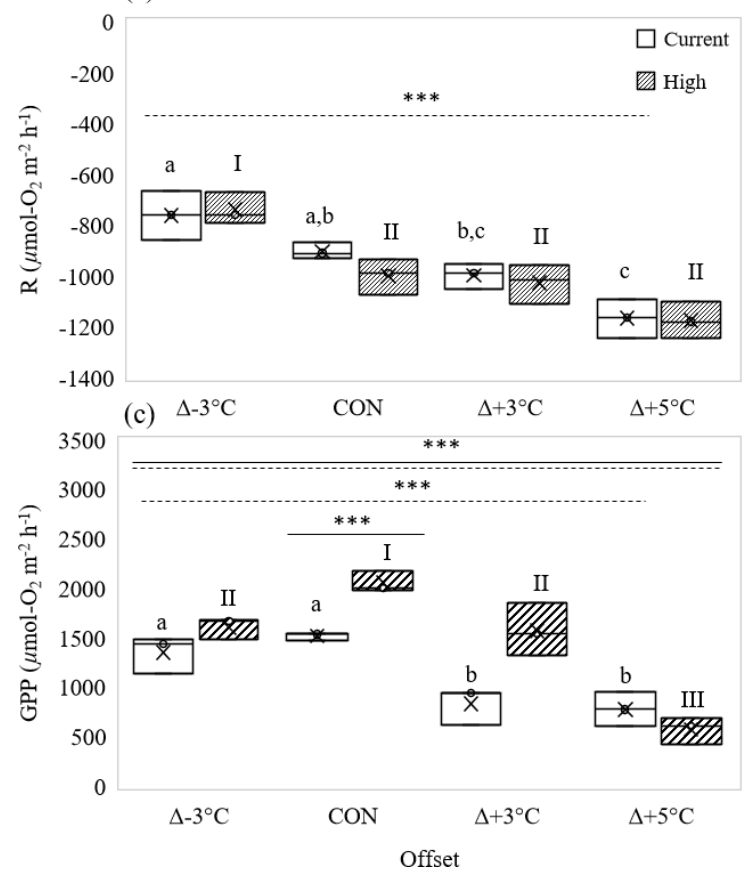

(b)
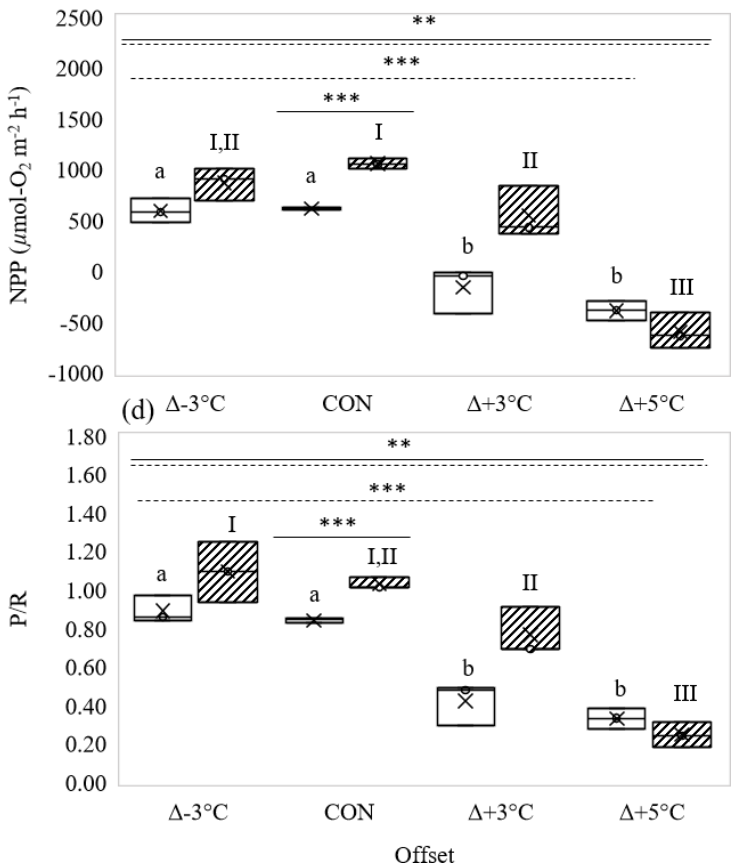

Figure 2. Effect of temperature on rates of (a) respiration $\left(R, \mu \mathrm{mol} \mathrm{O} \mathrm{m}^{-2} \mathrm{~h}^{-1}\right)$, (b) net primary production $\left(\mathrm{NPP}, \mu \mathrm{mol} \mathrm{O} \mathrm{m}^{-2} \mathrm{~h}^{-1}\right)$, (c) gross primary production (GPP, $\mu \mathrm{mol} \mathrm{O}_{2} \mathrm{~m}^{-2} \mathrm{~h}^{-1}$ ), and (d) $P / R$ under current (open boxes) and high- $p \mathrm{CO}_{2}$ conditions (hatched boxes). Panels show mean values " $x$ " at three temperature offsets from control $\left(\mathrm{CON}=23^{\circ} \mathrm{C}\right)$. Middle horizontal line in each box is the exclusive median, with the start of the upper and lower quartiles represented by the top and bottom edges of the box, respectively. Letters identify significantly different means across temperatures under current $p \mathrm{CO}_{2}$ conditions, and numerals identify significantly different means across temperatures under high- $p \mathrm{CO}_{2}$ conditions, where letters or numerals that are the same indicate no significant difference, as determined by post hoc Tukey's test. Solid and dashed horizontal lines identify significant effects of OA and temperature, respectively, where double solid and dashed lines identify significant interaction of temperature and OA (two-way ANOVA). Levels of significance are denoted with "**" for 0.05 , “**” for 0.01 , and “***" for 0.001. Data in Tables S3 and S4.

Table 2. $Q_{10}$ and $T_{\mathrm{opt}}$ values for current and high- $p \mathrm{CO}_{2}$ climates.

\begin{tabular}{lrr|rr|rr}
\hline & \multicolumn{2}{c|}{$R$} & \multicolumn{2}{c|}{ NPP } & \multicolumn{2}{c}{ GPP } \\
\cline { 2 - 7 } & Current & High & Current & High & Current & High \\
\hline$Q_{10}$ & 1.66 & 1.69 & 1.13 & 1.92 & 1.46 & 2.27 \\
$T_{\text {opt }}\left({ }^{\circ} \mathrm{C}\right)$ & 28 & 28 & 23 & 23 & 23 & 23 \\
\hline
\end{tabular}

high- $p \mathrm{CO}_{2}$ conditions NPP maintained net autotrophy in the light at $\Delta+3{ }^{\circ} \mathrm{C}$ and only resulted in net heterotrophy in the highest-temperature treatment (one-way interaction: $F_{3,8}=53.01, p<0.0001$; Fig. $2 b$ ).

GPP displayed a similar interactive stressor response to that described for NPP (two-way interaction: $F_{3,16}=9.39$, $p=0.0008$; Fig. 2c). Under current $p \mathrm{CO}_{2}$ conditions, GPP had a slight but insignificant rate increase from lowered to control temperatures $(\sim 12 \%)$, where rates significantly decreased at temperatures higher than control $(\sim 45$ and $\sim 50 \%$ for $\Delta+3$ and $\Delta+5^{\circ} \mathrm{C}$, respectively) (one-way interaction: $F_{3,8}=16.89, p=0.001$; Fig. $\left.2 \mathrm{c}\right)$. OA significantly increased GPP at ambient and $\Delta+3{ }^{\circ} \mathrm{C}$ temper- atures $\left(\mathrm{CO}_{2}\right.$ effect, two-way interaction: $F_{1,16}=24.77$, $p=0.0001 ;$ Fig. $2 \mathrm{c}$ ), resulting in a stronger temperature sensitivity in GPP under high- $p \mathrm{CO}_{2}$ conditions (one-way interaction: $F_{3,8}=40.90, p<0.0001$; Fig. $\left.2 c\right)$ than under current $p \mathrm{CO}_{2}$ conditions $(p=0.001)$. This increased sensitivity of GPP to temperature was supported by GPP $Q_{10}$ value differences between current and high- $p \mathrm{CO}_{2}$ conditions, increasing from 1.46 to 2.27 (Table 2).

The differences in $P / R$ among treatments further highlighted significant interaction of temperature and $p \mathrm{CO}_{2}$ (two-way interaction: $F_{3,16}=5.86, p=0.007$; Fig. $2 \mathrm{~d}$ ), suggesting the effect of $p \mathrm{CO}_{2}$ on primary productivity was strong enough to alter the overall productivity of the sediments. Under current $p \mathrm{CO}_{2}$ conditions, $P$ / $R$ reflected GPP with a clear separation between control and $\Delta-3^{\circ} \mathrm{C}$ sediments having a higher $P / R(0.84 \pm 0.01$ and $0.89 \pm 0.07$, respectively) than the significantly lower ratios calculated in increased-temperature cores $(0.42 \pm 0.11$ and $0.33 \pm 0.05$ for $\Delta+3$ and $\Delta+5^{\circ} \mathrm{C}$, respectively) (one-way interaction: $F_{3,8}=49.41, p<0.0001$; Fig. 2 d). Similarly, under high$p \mathrm{CO}_{2}$ conditions, the effect of GPP on $P / R$ was clear. The positive effect of high- $p \mathrm{CO}_{2}$ conditions on GPP pushed the 
$P / R$ ratio of $\Delta-3{ }^{\circ} \mathrm{C}$ and control temperature cores to $\sim 1$ $(1.09 \pm 0.16$ and $1.03 \pm 0.03$, respectively), suggesting the ecosystem shifted toward net autotrophy under those conditions. The positive effect of high- $p \mathrm{CO}_{2}$ conditions was also highlighted at $\Delta+3{ }^{\circ} \mathrm{C}$, with $P / R(0.77 \pm 0.13)$ remaining close to the current ecosystem ratio $(0.84 \pm 0.01)$ instead of significantly dropping like those calculated under current $p \mathrm{CO}_{2}$ conditions or in $\Delta+5^{\circ} \mathrm{C}$ cores $(0.25 \pm 0.04$, one-way interaction: $F_{3,8}=38.58, p<0.0001$; Fig. $2 \mathrm{~d}$ ).

\subsection{DIC fluxes}

DIC fluxes mirrored those of dissolved oxygen (Figs. 2 and 3), with both light and dark DIC: DO ratios near 1:1 (Fig. 4). In the dark, DIC reflected $R$ responses to temperature; like $R$, DIC responses to temperature did not differ with $p \mathrm{CO}_{2}$ (twoway interaction: $F_{3,16}=0.92, p=0.45$; Fig. $3 b$ ), and rates increased with increasing temperature (temperature effect, two-way interaction: $F_{3,16}=12.66, p=0.0002$; Fig. 3b). In the light, there was a significant interactive effect of temperature and $p \mathrm{CO}_{2}$ on DIC fluxes (two-way interaction: $F_{3,16}=12.01, p=0.0002$; Fig. $3 c$ ). Under current $p \mathrm{CO}_{2}$ conditions, DIC reflected the significant NPP responses to temperature, with DIC taken up at $\Delta-3^{\circ} \mathrm{C}$ and control temperatures and effluxed at $\Delta+3$ and $\Delta+5^{\circ} \mathrm{C}$ (one-way interaction: $F_{3,8}=21.33 p=0.0004$; Fig. $3 c$ ).

Net DIC responses were significantly affected by the interaction of $p \mathrm{CO}_{2}$ and temperature (two-way interaction: $F_{3,16}=9.69, p=0.001$; Fig. 3a). Like differences in $\mathrm{O}_{2}$, significant differences between $p \mathrm{CO}_{2}$ conditions were also measured in the $\Delta+3{ }^{\circ} \mathrm{C}$ temperature cores. At $\Delta+3{ }^{\circ} \mathrm{C}$, net DIC production in high- $p \mathrm{CO}_{2}$ cores was $\sim 62 \%$ lower than that measured at the same temperature under current $p \mathrm{CO}_{2}$ conditions (one-way interaction: $F_{3,4}=17.1$, $p=0.01$; Fig. 3a). This again reflected changes in light cycle production, with light DIC effluxes at $\Delta+3{ }^{\circ} \mathrm{C}$ under current $p \mathrm{CO}_{2}$ conditions becoming influxes under high- $p \mathrm{CO}_{2}$ conditions (132 \pm 74 to $-617 \pm 88 \mu \mathrm{mol} \mathrm{C} \mathrm{m}^{-2} \mathrm{~h}^{-1}$, Fig. 3a).

\subsection{DOC fluxes}

At current $p \mathrm{CO}_{2}$ levels, increasing temperature resulted in a significant shift in net DOC fluxes, going from effluxes at the two lower temperatures $\left(\Delta-3^{\circ} \mathrm{C}\right.$ and control) to uptakes at the two higher temperatures (one-way interaction: $F_{3,8}=6.96, p=0.013$; Fig. 5a). The relative light-and-dark cycle contributions of these net trends at current $p \mathrm{CO}_{2}$ levels were also affected by temperature (two-way interaction: $F_{3,16}=13.18, p=0.0001$; Fig. $5 b$ ). Significant changes in DOC fluxes in the dark shifted from an efflux at $\Delta-3^{\circ} \mathrm{C}$ to an uptake at control temperature, with higher uptake rates at $\Delta+5{ }^{\circ} \mathrm{C}(26 \%$ higher than control rates; one-way dark: $F_{3,8}=8.64, p=0.007$; Fig. 5b). In contrast, the highest DOC effluxes in the light were at control temperatures, significantly decreasing with both increasing and decreasing
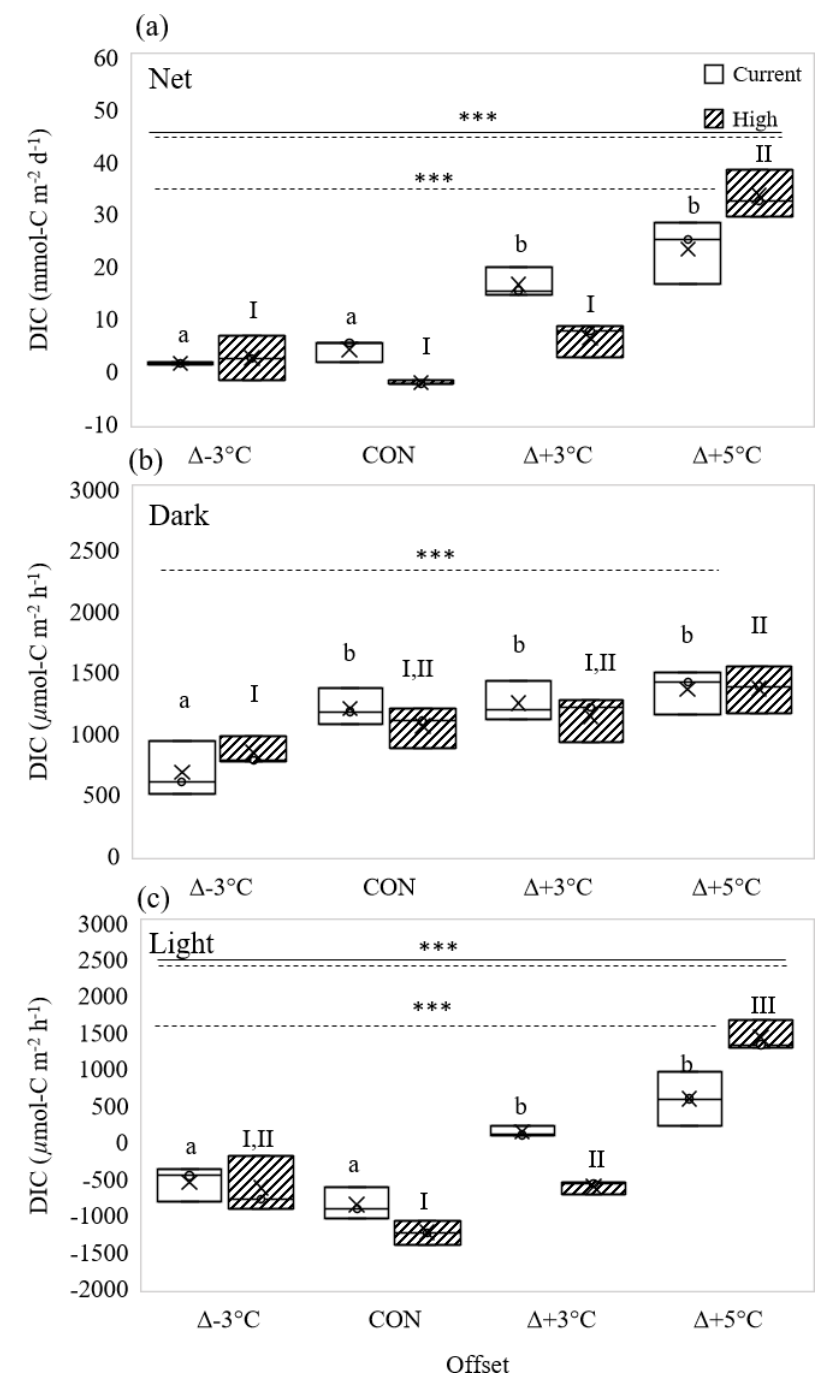

Figure 3. Effect of temperature on (a) net dissolved inorganic carbon (DIC) production (mmol C m${ }^{-2} \mathrm{~d}^{-1}$ ), and (b) dark and (c) light DIC fluxes $\left(\mu \mathrm{mol} \mathrm{C} \mathrm{m}^{-2} \mathrm{~h}^{-1}\right)$ under current (open boxes) and high$p \mathrm{CO}_{2}$ conditions (hatched boxes). Panels show mean values " $x$ " at three temperature offsets from control conditions $\left(\mathrm{CON}=23^{\circ} \mathrm{C}\right)$. Middle horizontal line in each box is the exclusive median, with the start of the upper and lower quartiles represented by the top and bottom edges of the box, respectively. Letters identify significantly different means across temperatures under current $p \mathrm{CO}_{2}$ conditions, and numerals identify significantly different means across temperatures under high- $p \mathrm{CO}_{2}$ conditions, where letters or numerals that are the same indicate no significant difference, as determined by a one-way ANOVA and post hoc Tukey's test. Solid and dashed horizontal lines identify significant effects of OA and temperature, respectively, where double solid and dashed lines identify significant interaction of temperature and OA (two-way ANOVA). Levels of significance are denoted with "**" for 0.05 , “*** for 0.01 , and "****" for 0.001. Data in Table S5. 


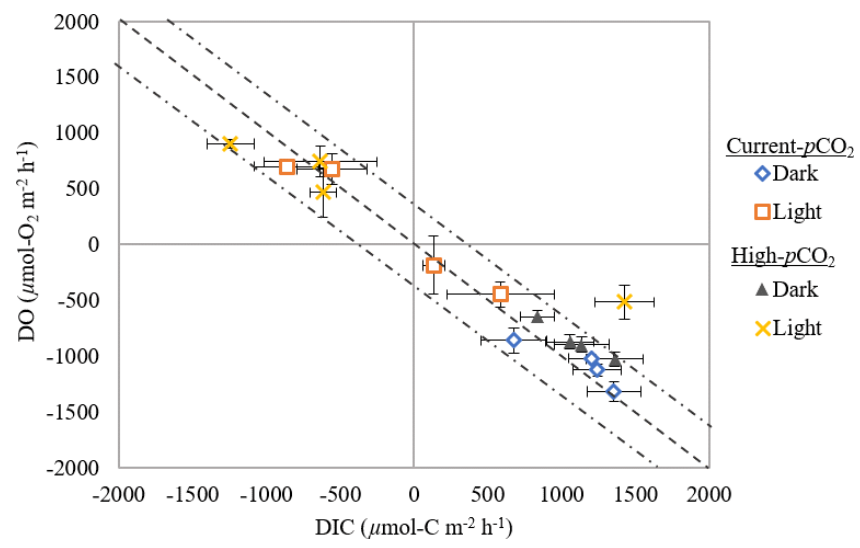

Figure 4. DIC: DO fluxes from sediment $\left(\mu \mathrm{mol} \mathrm{Cm}^{-2} \mathrm{~h}^{-1}\right.$ or $\mu \mathrm{mol} \mathrm{O}_{2} \mathrm{~m}^{-2} \mathrm{~h}^{-1}$ ) for all temperatures in dark-and-light cycles subject to current and high- $p \mathrm{CO}_{2}$ conditions (mean $\pm \mathrm{SD}$ ). Dashed line highlights the $1: 1$ ratio ( $\pm 18 \%$; Hopkinson, 1985), with values falling on this line likely a result of aerobic respiration. Arrows indicate the position values would fall in if sediments were experiencing chemical oxidation or anaerobic respiration.

temperatures to DOC fluxes around zero (one-way interaction: $F_{3,8}=16.76, p=0.001$; Fig. $5 b$ ).

High- $p \mathrm{CO}_{2}$ conditions alone (at ambient mean temperatures, $23^{\circ} \mathrm{C}$ ) had a significant effect on net DOC, shifting from a slight efflux at current $p \mathrm{CO}_{2}$ levels $\left(\sim 0.5 \mathrm{mmol} \mathrm{C} \mathrm{m}^{-2} \mathrm{~d}^{-1}\right)$ to a significant uptake at high $p \mathrm{CO}_{2}$ levels $\left(\sim 10.9 \mathrm{mmol} \mathrm{C} \mathrm{m}^{-2} \mathrm{~d}^{-1}\right.$; one-way interaction: $F_{3,4}=25.1, p=0.007$; Fig. 5a). The trend in temperature response was similar for current and high- $p \mathrm{CO}_{2}$ conditions (two-way interaction: $F_{3,16}=0.88, p=0.47$; Fig. 5a), but there was a significant shift from small efflux at lower temperatures to considerable uptakes at all temperatures under high- $p \mathrm{CO}_{2}$ conditions (two-way $\mathrm{CO}_{2}$ effect: $F_{1,16}=61.46$, $p<0.0001$; Fig. 5a). Differences between dark and light DOC fluxes under high- $p \mathrm{CO}_{2}$ conditions were independent of temperature (two-way interaction: $F_{3,16}=1.94, p=0.16$; Fig. 5c), with the overall magnitude of influxes in the dark being significantly greater than those in the light (two-way light condition: $F_{1,16}=15.83, p=0.001$; Fig. 5 c). Loss of statistically different temperature responses for high- $p \mathrm{CO}_{2}$ light and dark responses (temperature effect, two-way interaction: $F_{3,16}=1.05, p=0.40$; Fig. $5 \mathrm{c}$ ) was in large part due to within-treatment variability in the high- $p \mathrm{CO}_{2}$ cores.

\section{Discussion}

An important component of this study was testing the interaction and individual effects of warming and OA on DOC processing. This was necessarily achieved through a comparison of core incubations occurring in different weeks. As such, it is important to consider the limitations of this approach. Control treatments in different weeks would ideally
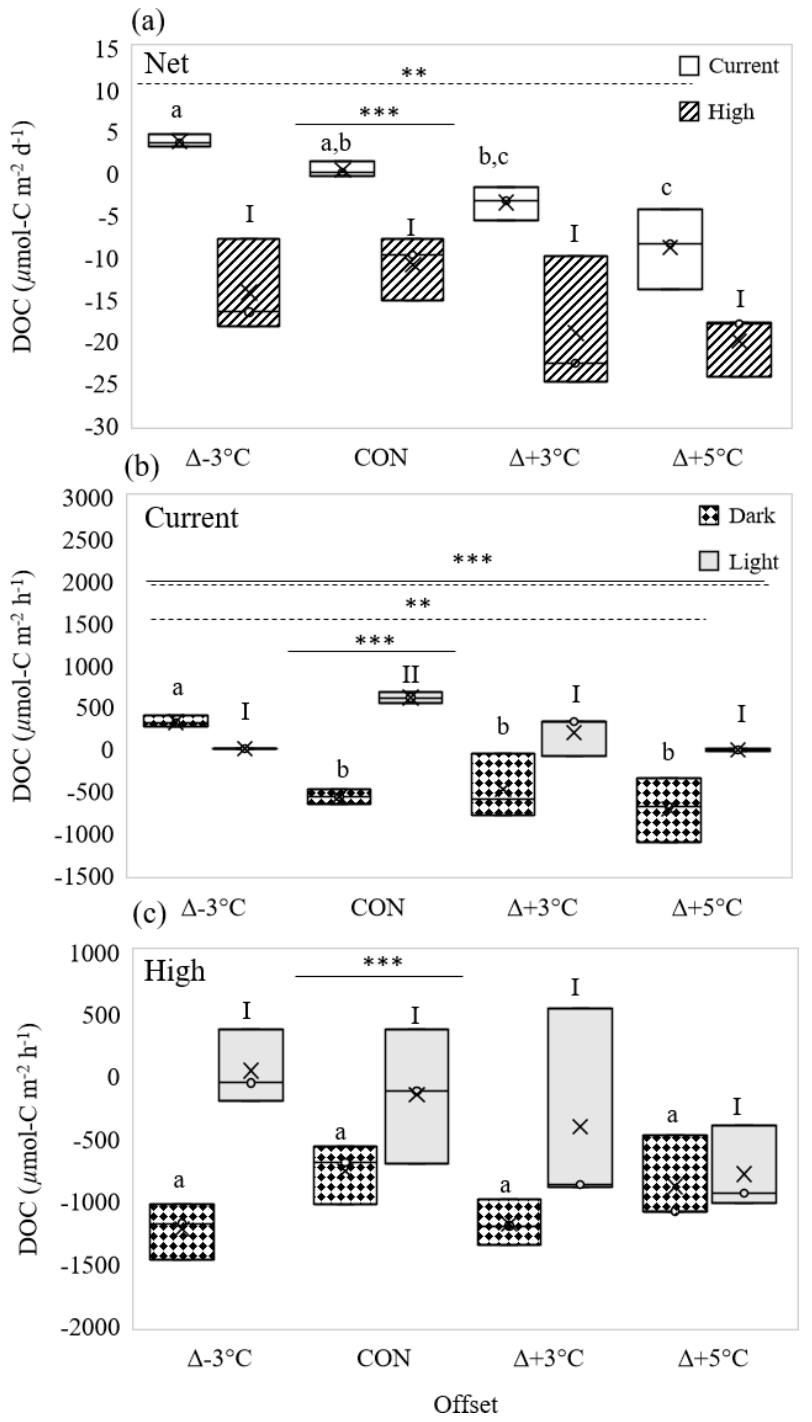

Figure 5. Effect of three temperature offsets from control (CON $=23^{\circ} \mathrm{C}$ ) on (a) net dissolved organic carbon (DOC) fluxes $\left(\mu \mathrm{mol} \mathrm{C} \mathrm{m}{ }^{-2} \mathrm{~d}^{-1}\right.$ ) under current (open boxes) and high- $p \mathrm{CO}_{2}$ conditions (hatched boxes). Light (grey boxes) and dark fluxes (spotted boxes) of DOC ( $\mu \mathrm{mol} \mathrm{Cm}^{-2} \mathrm{~h}^{-1}$ ) for (b) current $p \mathrm{CO}_{2}$ and (c) high- $p \mathrm{CO}_{2}$ conditions. In panel (a) letters identify significantly different means across temperatures under current $p \mathrm{CO}_{2}$ conditions, and numerals identify significantly different means across temperatures under high- $p \mathrm{CO}_{2}$ conditions; in panels (b) and (c) letters identify significantly different means across temperatures in dark cycles, and numerals identify significantly different means across temperatures in light cycles. Letters or numerals that are the same indicate no significant difference, as determined by a one-way ANOVA and post hoc Tukey's test. Solid and dashed horizontal lines identify significant effects of $p \mathrm{CO}_{2}$ or light and temperature, respectively, where double solid and dashed lines identify significant interaction of temperature and light (two-way ANOVA). Levels of significance are denoted with "**” for 0.05 , “**” for 0.01 , and «***" for 0.001. Data in Table S6. 
be the same in all respects, but there were some differences. For instance, NPP and $R$ were higher in the incubation week for current $p \mathrm{CO}_{2}$ conditions (Table $\mathrm{S} 2$ ), likely due to small changes in environmental conditions, such as salinity differences ( 24 versus 17.7 for current and high- $p \mathrm{CO}_{2}$ conditions, respectively; Table 1). However, these differences did not significantly affect DOC fluxes, nor the heterotrophy of the sediments $(P / R=0.84 \pm 0.01$ and $0.83 \pm 0.04$; Table S2). Moreover, sediments in separate weeks maintained the same OM content $(\sim 3.5 \%)$ and molar $\mathrm{C}: \mathrm{N}$ ratio $(\sim 16)$, suggesting that differences in processing have very little short-term impact on the overall OM pool in the sediment due to the OM pool size being about 3 orders of magnitude higher than any diel flux (organic carbon pool $\sim 12000 \mathrm{mM}$ ). Thus, because all conditions in the laboratory setup were the same for each incubation (with the exception of $p \mathrm{CO}_{2}$ in treatment tanks, which was intentionally manipulated to be different), the difference in fluxes between controls was attributed to differences in when the sediments and overlying waters were collected. Therefore, the scaling of NPP and $R$ (Table S3) was done for the sake of treatment comparison, resulting in scaled rates within $13 \%$ of actual measured values, which had a negligible effect on $P / R(<1 \%$ across all treatments). The final NPP and $R$ rates in comparisons across treatments should thus be considered relative to control rates and be interpreted as approximate values $( \pm 13 \%)$.

Understanding current ecosystem functioning is of primary interest when trying to determine how disturbances in the environment may change metabolic rates and pathways of OM mineralization (Jørgensen, 1996; D’ Avanzo et al., 1996; Malone and Conley, 1996). Based on unadjusted $R$ rates, the nearly $1: 1$ ratio of DIC production to $\mathrm{O}_{2}$ consumption in the dark (respiratory quotient of $\sim 1.13 \pm 0.05$; Fig. 4) suggests that aerobic respiration dominated the sediments (Eyre and Ferguson, 2002). Similarly, unadjusted NPP rates suggest that aerobic processes dominated benthic production in the light, with a $1: 1$ ratio of $\mathrm{O}_{2}$ and DIC fluxes (Fig. 4; Eyre and Ferguson, 2002). Sediments in the current study were net heterotrophic, with a $P / R$ in control cores of $\sim 0.84 \pm 0.01$ and $\sim 0.83 \pm 0.04$ during current- and high$p \mathrm{CO}_{2}$ incubation weeks, respectively. Despite the undeniable range of $P / R$ ratios that unvegetated estuarine sediments may experience (1.2 (Oakes et al., 2012) to 0.01 (Ferguson and Eyre, 2013)), the ratios in the current study were similar to mean global estimates for unvegetated estuarine sediments $(\sim 0.82$, calculated from values in Duarte et al., 2005) and calculated from $P$ and $R$ values of 22 estuaries globally ( $\sim 0.87$, compiled by Smith and Hollibaugh, 1993), suggesting that the metabolic function of sediments in the current study are representative of estuarine sediments globally and the impacts observed in this study should be broadly applicable.

\subsection{DOC fuels benthic respiration}

DOC appeared to be a significant driver of benthic respiration (Fig. 5b). At control temperatures $\left(23^{\circ} \mathrm{C}\right)$ net DOC fluxes were near zero $\left(0.47 \pm 0.93 \mathrm{mmol} \mathrm{C} \mathrm{m}^{-2} \mathrm{~d}^{-1}\right)$, indicating that the diel production and uptake of DOC across the sediment-water interface were balanced (Fig. 5a). The control rates in the present study were close to benthic DOC flux rates reported for subtropical estuarine sediments in most seasons, $\sim 1.5 \mathrm{mmol} \mathrm{C} \mathrm{m}^{-2} \mathrm{~d}^{-1}$, except summer (Maher and Eyre, 2010). Relative to our control (summer) rates, Maher and Eyre (2010) reported higher net DOC flux rates $\left(\sim 10 \mathrm{mmol} \mathrm{C} \mathrm{m}^{-2} \mathrm{~d}^{-1}\right)$ as a result of DOC effluxes in both the light and dark (Maher and Eyre, 2010). We observed similar light DOC effluxes $\left(610 \mu \mathrm{mol} \mathrm{C} \mathrm{m}{ }^{-2} \mathrm{~h}^{-1}\right)$ to summer sediments in Maher and Eyre (2010) $\left(\sim 647 \mu \mathrm{mol} \mathrm{C} \mathrm{m}^{-2} \mathrm{~h}^{-1}\right)$, whereas dark DOC uptake was observed in the current study $\left(-571 \mu \mathrm{mol} \mathrm{C} \mathrm{m}^{-2} \mathrm{~h}^{-1}\right)$, and Maher and Eyre (2010) reported dark DOC effluxes $\left(254 \mu \mathrm{mol} \mathrm{C} \mathrm{m}{ }^{-2} \mathrm{~h}^{-1}\right)$. This release of DOC in the dark was attributed to enhanced microbial coupling in the sediments in warmer temperatures (Maher and Eyre, 2010). In the current study, and in previous reports, DOC uptake suggests that bacteria not only intercepted DOC produced from within the pore waters (potentially satisfying up to $60 \%$ of total mean bacterial production; Boto et al., 1989) but also took up available DOC from the water column to satisfy its metabolic requirements (Boto et al., 1989; Brailsford et al., 2019), effectively acting as a DOC sink. Under conditions of reduced light availability and/or intensity, sediments are expected to have an amplified heterotrophic response in addition to a reduction in microalgal production of DOC.

\subsection{OA increases DOC assimilation}

Positive responses in primary production were associated with OA. The $\sim 72 \%$ increase in NPP rates at ambient temperatures was consistent with general stimulation of primary production in finer sediments with increased DIC availability (Vopel et al., 2018; Oakes and Eyre, 2014). Sediments may become DIC-limited when algal demand is relatively high compared to porewater supply of $\mathrm{CO}_{2}$ (Cook and Røy, 2006), and MPBs therefore may benefit from an increase in $\mathrm{CO}_{2}$ availability. MPBs in fine sediments are restricted to dissolved substrates (i.e. nutrients and DIC) accessed via diffusion from deeper and adjacent sediments, and the overlying water column (Boudreau and Jørgensen, 2001). This makes them more likely to deplete accessible DIC than MPBs in permeable sediments. Primary producers in permeable sediments, like those in reef ecosystems, therefore do not often experience the same increase in primary production with increased $\mathrm{CO}_{2}$ (Trnovsky et al., 2016; Cyronak and Eyre, 2016; Eyre et al., 2018; Cook and Røy, 2006; Vopel et al., 2018). As well as differences in diffusive versus advective modes of 
solute transfer between the sediment types (Cook and Røy, 2006), variable response may also be attributable to sandier sediments being limited by other factors such as nutrient and OM availability, given that coarser sediments are generally more oligotrophic (Admiraal, 1984; Heip et al., 1995). In comparison, nutrients were non-limiting in the less permeable sediments used in the current study, based on nutrient concentrations that increased during all incubations (see the Supplement and Table S7). MPB growth rates in sediments with low permeability are more likely limited by DIC availability. Primary productivity responses to $p \mathrm{CO}_{2}$ would likely differ in permeable sediments where general access to $\mathrm{CO}_{2}$ is greater.

Given that MPBs exude carbon (Maher and Eyre, 2010), we would expect increased GPP to correspond with increased DOC production and flux. However, although OA stimulated primary production (Fig. 2), we instead saw increased DOC uptake in the dark (Fig. 5). A likely explanation is that bacterial uptake of DOC was stimulated through the provision of labile carbon from MPBs (Morán et al., 2011; Hardison et al., 2013). As such, DOC appeared to fuel much of the dark cycle respiration, as DOC uptake in the dark reflected dark DIC production (respiration), except for sediments at $\Delta-3{ }^{\circ} \mathrm{C}$ under current $p \mathrm{CO}_{2}$ conditions. Under current $p \mathrm{CO}_{2}$ conditions, uptake of DOC in the dark accounted for only $\sim 50 \%$ of the DIC respired in the dark. The portion of DIC accounted for by dark DOC uptake increased from 50 to $100 \%$ under the high- $p \mathrm{CO}_{2}$ conditions. In part, this may have been due to increased availability of labile organic carbon (Moran and Hodson, 1990) arising from the increase in NPP under high- $p \mathrm{CO}_{2}$ conditions across all temperatures (Fig. 2b), which would reduce the need for bacteria to synthesize ectoenzymes (Chróst, 1991, 1992), resulting in more rapid turnover of carbon to the water column.

\subsection{Warming drives increased heterotrophy and DOC assimilation}

Sediments in this study, like other manipulative studies in both permeable sands (Lantz et al., 2017; Trnovsky et al., 2016) and cohesive sediments (Apple et al., 2006), demonstrated increased heterotrophy with increased temperature. This shift to heterotrophy is often attributed to the imbalance in the thermal sensitivity of heterotrophic over autotrophic metabolism (Yang et al., 2016; Allen et al., 2005). More specifically, differences in activation energy dictated by differences in physiology and biochemical processes (Patching and Rose, 1970; Apple et al., 2006) result in increases in heterotrophic activity with increasing temperature than exceed increases in autotrophic activity (Yang et al., 2016). However, in this study, under current $p \mathrm{CO}_{2}$ conditions, the increases in $R$ and GPP from $\Delta-3{ }^{\circ} \mathrm{C}$ to control temperatures were similar ( $\sim 16$ and $\sim 11 \%$, respectively), whereas at higher temperatures GPP decreases far exceeded increases in $R$ ( $7 \times$ and $3 \times$ for 26 and $28^{\circ} \mathrm{C}$, respectively). There- fore, unlike previous studies, decreases in MPB productivity at higher temperatures appeared to be a greater driver towards heterotrophy than increases in respiration rates. In other words, temperature increases not only increased the rate of DOC uptake but also likely decreased the rate of DOC production.

\subsubsection{Warming reduces GPP and DOC production under current $p \mathrm{CO}_{2}$ conditions}

Primary production is the main source of DOC in marine ecosystems (Wagner et al., 2020). Decreasing trends in GPP with warming under current $p \mathrm{CO}_{2}$ conditions seen here have been described previously where photosynthetic growth and production decline at higher temperatures (Thomas et al., 2012). Photosynthetic productivity is often linked to seasonal temperature (Apple et al., 2006), which is also associated with differences in environmental factors such as light, nutrient concentrations, and dissolved organic matter (DOM) quality and availability (Geider, 1987; Herrig and Falkowski, 1989). Although the relative availability of light and nutrients does influence productivity rates (Kana et al., 1997) and would be expected to influence in situ seasonal production, the current study controlled light and initial nutrient concentrations in the water column to isolate the effect of temperature. Thus, decreasing GPP was driven by warming, suggesting that MPBs in these subtropical sediments likely had a temperature optimum around current mean summer temperatures of $\sim 23^{\circ} \mathrm{C}$ (GPP: $1515 \pm 37 \mu \mathrm{mol} \mathrm{O}_{2} \mathrm{~m}^{-2} \mathrm{~h}^{-1}$; Fig. 2c). Longer-term warming could allow for possible migration of more tolerant species to settle from lower latitudes (Hallett et al., 2018), shifting the composition of the benthic community. The introduction of more tolerant species could reduce the increase in heterotrophy and net DOC removal from the water column seen here. However, the species diversity of the estuarine sediments will ultimately decrease as they are pushed to temperature extremes (Thomas et al., 2012), reducing the functional redundancy of the microbial community. This decreased functional redundancy has the potential to make unvegetated estuarine sediments less resilient to environmental perturbations under future climate conditions.

\subsubsection{Warming increases respiration and DOC assimilation}

Unlike photosynthetic productivity, heterotrophic respiration often has a linear rate increase with temperature to the thermal optimum due to heterotrophs not being constrained by the same abiotic variables (e.g. nutrient and light availability) as primary producers (Apple et al., 2006, 2008; Geider, 1987; Yap et al., 1994). In this study, respiration rates under both current and high $p \mathrm{CO}_{2}$ conditions increased from the lowest rates measured at $\Delta-3{ }^{\circ} \mathrm{C}$ to maximum rates $(>50 \%$ greater) at $\Delta+5^{\circ} \mathrm{C}$ (Fig. 2a). Consistent with overall lower 
respiration rates relative to other subtropical unvegetated sediments $\left(\sim 900\right.$ to $\sim 1500 \mu \mathrm{mol} \mathrm{O} \mathrm{m}^{-2} \mathrm{~h}^{-1}$; Ferguson and Eyre, 2013), the temperature dependence of respiration under both current and high- $p \mathrm{CO}_{2}$ conditions $\left(Q_{10}=1.66\right.$ and 1.69 , respectively) was slightly lower than is typical for biological systems $\left(Q_{10}=2\right.$; Valiela, 1995) but similar to temperature dependence described in other estuarine systems $\left(Q_{10}=1.5-1.9\right.$; Morán et al., 2011), with values towards the lower end of this range possibly being a result of resource limitation (López-Urrutia and Morán, 2007).

A potential limiting resource for bacteria in estuarine sediments is DOM (Church, 2008), ultimately controlling the flow of carbon through the microbial loop (Kirchman and Rich, 1997). However, in the presence of sufficient DOM, warming has been associated with increased bacterial DOM incorporation (Kirchman and Rich, 1997). In line with this, increased uptake of DOC at higher temperatures and efflux at lower temperatures was observed. Although DOC is mainly produced by photoautotrophs, DOC can be produced in the dark through, for example, chemodegradation of detrital organic carbon and cell lysis by viruses and during grazing (Carlson, 2002). As such, the efflux of DOC in the dark at $\Delta-3{ }^{\circ} \mathrm{C}$ suggests that heterotrophic bacterial productivity, and therefore DOC uptake, was reduced by lowered temperatures (Raymond and Bauer, 2000), resulting in a failure to intercept all DOC produced in the pore waters. This failure to intercept DOC may be compounded if nutrient supply is limited (Brailsford et al., 2019), as it is common for heterotrophic bacteria to rely on refractory DOC when labile sources are not readily available (Chróst, 1991), which can occur under conditions of nutrient-limited biological productivity (Allen, 1978).

\subsubsection{Global estuarine loss of DOC from unvegetated sediments in the future}

Up to $3.5 \times$ more DOC reaches the ocean interior from coastal areas than the open ocean (Duarte, 2017; KrauseJensen and Duarte, 2016; Hansell et al., 2009). As such, small changes to the coastal export of DOC may have a disproportionately large influence on the global DOC budget. Our findings suggest a reduced export of DOC to the ocean from the coastal zone under high- $p \mathrm{CO}_{2}$ conditions, across the full $8^{\circ} \mathrm{C}$ temperature range due to changes in carbon processing within unvegetated sediments. Despite the lack of seasonality in the study, the inclusion of an $8^{\circ} \mathrm{C}$ temperature range, including temperatures below current mean temperatures, suggests that seasonal temperature variation is unlikely to have a significant effect on the relative change in DOC in the future (Fig. 5). Although any upscaling of a single controlled experiment to a global scale is highly speculative, we believe it is valuable to demonstrate the potential for a high$p \mathrm{CO}_{2}$ climate to cause globally significant change in DOC export from coastal zones. Furthermore, putting our findings in a global context provides a guideline value for potential change. The following estimates should be considered in this context, and it should be expected that different hydrodynamic settings, sediment and/or sediment community composition, and sources of organic matter could affect the outcome. For example, the response to warming and $p \mathrm{CO}_{2}$ may be different for pelagic communities and/or in deeper waters that are subject to stratification ( $\mathrm{Li}$ et al., 2020), where access to nutrients and $\mathrm{CO}_{2}$ may become limiting (Rost et al., 2008). We have applied our results to global coastal DOC exports (Maher and Eyre, 2010; Duarte, 2017) as an initial step in estimating responses of unvegetated sediment habitats to future high- $p \mathrm{CO}_{2}$ climate. We do not assume that the responses of unvegetated sediments to the future climate found here are applicable to other ecosystems dominated by macrophytes, and we thus did not apply our findings to vegetated coastal habitats.

To estimate total DOC export from coastal zone in a future high- $p \mathrm{CO}_{2}$ climate of $\Delta+3^{\circ} \mathrm{C}$ and $\mathrm{OA}$, the sediment uptake rate of $19 \pm 4 \mathrm{mmol} \mathrm{C} \mathrm{m}^{-2} \mathrm{~d}^{-1}$ was scaled to the global surface area of unvegetated estuarine sediments $\left(1.8 \times 10^{12} \mathrm{~m}^{2}\right.$; Costanza et al., 1997). On this basis, an estimated $150 \mathrm{Tg} \mathrm{C}$ would be removed from the coastal zone by unvegetated estuarine sediments annually under OA conditions with an accompanying $3{ }^{\circ} \mathrm{C}$ temperature increase. To then calculate the potential impact of this uptake, we applied our estimates to existing future global coastal DOC export estimates (Maher and Eyre, 2010; Duarte, 2017). Mean benthic DOC export from estuaries, including intertidal and vegetated habitats, has been estimated at $168 \mathrm{Tg} \mathrm{C} \mathrm{yr}^{-1}\left(90-247 \mathrm{Tg} \mathrm{C} \mathrm{yr}^{-1}\right)$ (Maher and Eyre, 2010). Under this scenario, the switch to DOC uptake by sediments under future climate conditions (Fig. 5a) would result in $\sim 90 \%$ reduction in total mean estuarine DOC export (Maher and Eyre, 2010), decreasing the load from $\sim 168$ to $\sim 18 \mathrm{Tg} \mathrm{C} \mathrm{yr}^{-1}$. Other global estimates of DOC exported from coastal vegetated ecosystems range from 114 up to $1853 \mathrm{Tg} \mathrm{C} \mathrm{yr}^{-1}$ (Duarte, 2017), with scaled estimates suggesting unvegetated estuarine sediments may consume 8 to $132 \%$ of this DOC under a future high$p \mathrm{CO}_{2}$ climate. As such, this basic upscaling suggests that, by impacting DOC fluxes in unvegetated sediments, future climate conditions have the potential to significantly impact global DOC export from coastal systems to the open ocean. This has implications for global marine productivity and carbon transfer to the ocean interior (Krause-Jensen and Duarte, 2016). However, to get a more accurate insight into global carbon cycling, the response of DOC export from estuarine vegetated habitats to future climate also needs to be studied.

Data availability. Archived data will be accessible on PANGAEA at https://doi.org/10.1594/PANGAEA.924460 (Simone et al., 2020). 
Supplement. The supplement related to this article is available online at: https://doi.org/10.5194/bg-18-1823-2021-supplement.

Author contributions. All listed authors have contributed substantially to preparation and drafting of this paper and have approved the final submitted manuscript. Specifically, MNS conceived the project, collected data, ran data analysis and interpretation, and led the writing of the manuscript. KGS, JMO, and BDE helped conceive the project, contributed to interpretation, and helped draft the manuscript.

Competing interests. The authors declare that they have no conflict of interest.

Acknowledgements. Thanks are extended to Paul Kelly, Iain Alexander, Matheus Carvalho, Natasha Carlson-Perret, Jacob Yeo, and Nicola Camillini for their assistance in the field and support in the laboratory. Special thanks to Zoey Kennedy allowing access to her property for sample collection. This work was supported by an SESE Postgraduate Scholarship from Southern Cross University, Lismore, NSW, Australia.

Financial support. This research has been supported by ARC Discovery projects (grant nos. DP150102092 and DP160100248).

Review statement. This paper was edited by Christoph Heinze and reviewed by two anonymous referees.

\section{References}

Admiraal, W.: The ecology of estuarine sediment-inhabiting diatoms, in: Progress in phycological Research, edited by: Round, F. E., and Chapman, D. J., Biopress, Bristol, 269-322, 1984.

Allen, A., Gillooly, J., and Brown, J.: Linking the global carbon cycle to individual metabolism, Funct. Ecol., 19, 202-213, https://doi.org/10.1111/j.1365-2435.2005.00952.x, 2005.

Allen, H. L.: Low molecular weight dissolved organic matter in five soft-water ecosystems: a preliminary study and ecological implications: With 3 figures and 2 tables in the text and on 1 folder, Internationale Vereinigung für theoretische und angewandte Limnologie: Verhandlungen, 20, 514-524, 1978.

Apple, J., Smith, E., and Boyd, T.: Temperature, Salinity, Nutrients, and the Covariation of Bacterial Production and Chlorophylla in Estuarine Ecosystems, J. Coast. Res., 2008, 59-75, https://doi.org/10.2112/SI55-005.1, 2008.

Apple, J. K., del Giorgio, P. A., and Kemp, W. M.: Temperature regulation of bacterial production, respiration, and growth efficiency in a temperate salt-marsh estuary, Aquat. Microb. Ecol., 43, 243-254, https://doi.org/10.3354/ame043243, 2006.

Azam, F.: Microbial control of oceanic carbon flux: the plot thickens, Science, 280, 694-696, https://doi.org/10.1126/science.280.5364.694, 1998.
Bauer, J. and Bianchi, T.: Dissolved Organic Carbon Cycling and Transformation, in: Treatise on estuarine and coastal science, edited by: Wolanski, E. and McLusky, D. S., Academic Press, Waltham, 7-67, 2011.

Bauer, J. E. and Druffel, E. R. M.: Ocean margins as a significant source of organic matter to the deep open ocean, Nature, 392 , 482-485, https://doi.org/10.1038/33122, 1998.

Boto, K. G., Alongi, D. M., and Nott, A. L.: Dissolved organic carbon-bacteria interactions at sediment-water interface in a tropical mangrove system, Mar. Ecol.-Prog. Ser., 51, 243-251, https://doi.org/10.3354/meps051243, 1989.

Boudreau, B. P. and Jørgensen, B. B.: The benthic boundary layer: Transport processes and biogeochemistry, Oxford University Press, New York, 2001.

Brailsford, F. L., Glanville, H. C., Golyshin, P. N., Johnes, P. J., Yates, C. A., and Jones, D. L.: Microbial uptake kinetics of dissolved organic carbon (DOC) compound groups from river water and sediments, Sci. Rep.-UK, 9, 11229, https://doi.org/10.1038/s41598-019-47749-6, 2019.

Carlson, C. A.: Production and Removal Processes, in: Biogeochemistry of Marine Dissolved Organic Matter, edited by: Hansell, D. A. and Carlson, C. A., Academic Press, San Diego, 2002.

Chróst, R. J.: Ectoenzymes in aquatic environments: Microbial strategy for substrate supply, SIL Proceedings, 1922-2010, 24, 2597-2600, https://doi.org/10.1080/03680770.1989.11900030, 1991.

Chróst, R. J.: Significance of bacterial ectoenzymes in aquatic environments, Hydrobiologia, 243, 61-70, https://doi.org/10.1007/BF00007020, 1992.

Church, M. J.: Resource control of bacterial dynamics in the sea, in: Microbial ecology of the oceans, edited by: Kirchman, D. L., 335-382, 2008.

Cook, P. L., Veuger, B., Böer, S., and Middelburg, J. J.: Effect of nutrient availability on carbon and nitrogen incorporation and flows through benthic algae and bacteria in nearshore sandy sediment, Aquat. Microb. Ecol., 49, 165-180, https://doi.org/10.3354/ame01142, 2007.

Cook, P. L. M. and Røy, H.: Advective relief of $\mathrm{CO}_{2}$ limitation in microphytobenthos in highly productive sandy sediments, Limnol. Oceanogr., 51, 1594-1601, https://doi.org/10.4319/lo.2006.51.4.1594, 2006.

Cook, P. L. M., Butler, E. C., and Eyre, B. D.: Carbon and nitrogen cycling on intertidal mudflats of a temperate Australian estuary. I. Benthic metabolism, Mar. Ecol.-Prog. Ser., 280, 25-38, https://doi.org/10.3354/meps280025, 2004.

Costanza, R., d'Arge, R., De Groot, R., Farber, S., Grasso, M., Hannon, B., Limburg, K., Naeem, S., O’Neill, R. V., and Paruelo, J.: The value of the world's ecosystem services and natural capital, Nature, 387, 253, https://doi.org/10.1038/387253a0, 1997.

Cyronak, T. and Eyre, B. D.: The synergistic effects of ocean acidification and organic metabolism on calcium carbonate $\left(\mathrm{CaCO}_{3}\right)$ dissolution in coral reef sediments, Mar. Chem., 183, 1-12, https://doi.org/10.1016/j.marchem.2016.05.001, 2016.

Czerny, J., Schulz, K. G., Boxhammer, T., Bellerby, R. G. J., Büdenbender, J., Engel, A., Krug, S. A., Ludwig, A., Nachtigall, K., Nondal, G., Niehoff, B., Silyakova, A., and Riebesell, U.: Implications of elevated $\mathrm{CO}_{2}$ on pelagic carbon fluxes in an Arctic mesocosm study - an elemental mass balance approach, 
Biogeosciences, 10, 3109-3125, https://doi.org/10.5194/bg-103109-2013, 2013.

D’Avanzo, C., Kremer, J. N., and Wainright, S. C.: Ecosystem production and respiration in response to eutrophication in shallow temperate estuaries, Mar. Ecol.-Prog. Ser., 141, 263-274, https://doi.org/10.3354/meps141263, 1996.

Dickson, A.: Standards for Ocean Measurements, Oceanography, 23, 34-47, https://doi.org/10.5670/oceanog.2010.22, 2010.

Dickson, A. G. and Millero, F. J.: A comparison of the equilibrium constants for the dissociation of carbonic acid in seawater media, Deep-Sea Res. Pt. A, 34, 1733-1743, https://doi.org/10.1016/0198-0149(87)90021-5, 1987.

Dickson, A. G.: Thermodynamics of the dissociation of boric acid in potassium chloride solutions from 273.15 to $318.15 \mathrm{~K}$, J. Chem. Eng. Data., 35, 253-257, https://doi.org/10.1021/je00061a009, 1990.

Duan, S.-W. and Kaushal, S. S.: Warming increases carbon and nutrient fluxes from sediments in streams across land use, Biogeosciences, 10, 1193-1207, https://doi.org/10.5194/bg-10-11932013, 2013.

Duarte, C. M.: Reviews and syntheses: Hidden forests, the role of vegetated coastal habitats in the ocean carbon budget, Biogeosciences, 14, 301-310, https://doi.org/10.5194/bg-14-301-2017, 2017.

Duarte, C. M., Middelburg, J. J., and Caraco, N.: Major role of marine vegetation on the oceanic carbon cycle, Biogeosciences, 2, 1-8, https://doi.org/10.5194/bg-2-1-2005, 2005.

Duarte, C. M. and Cebrián, J.: The fate of marine autotrophic production, Limnol. Oceanogr., 41, 1758-1766, https://doi.org/10.4319/lo.1996.41.8.1758, 1996.

Engel, A., Händel, N., Wohlers, J., Lunau, M., Grossart, H.-P., Sommer, U., and Riebesell, U.: Effects of sea surface warming on the production and composition of dissolved organic matter during phytoplankton blooms: results from a mesocosm study, J. Plankton Res., 33, 357-372, https://doi.org/10.1093/plankt/fbq122, 2011.

Engel, A., Borchard, C., Piontek, J., Schulz, K. G., Riebesell, U., and Bellerby, R.: $\mathrm{CO}_{2}$ increases ${ }^{14} \mathrm{C}$ primary production in an Arctic plankton community, Biogeosciences, 10, 1291-1308, https://doi.org/10.5194/bg-10-1291-2013, 2013.

Eyre, B. D.: Regional evaluation of nutrient transformation and phytoplankton growth in nine river-dominated sub-tropical east Australian estuaries, Mar. Ecol.-Prog. Ser., 205, 61-83, https://doi.org/10.3354/meps205061, 2000.

Eyre, B. D. and Ferguson, A. J.: Comparison of carbon production and decomposition, benthic nutrient fluxes and denitrification in seagrass, phytoplankton, benthic microalgae- and macroalgaedominated warm-temperate Australian lagoons, Mar. Ecol.-Prog. Ser., 229, 43-59, https://doi.org/10.3354/meps229043, 2002.

Eyre, B. D. and Pont, D.: Intra-and inter-annual variability in the different forms of diffuse nitrogen and phosphorus delivered to seven sub-tropical east Australian estuaries, Estuar. Coast. Shelf S., 57, 137-148, https://doi.org/10.1016/S0272-7714(02)003372, 2003.

Eyre, B. D., Cyronak, T., Drupp, P., De Carlo, E. H., Sachs, J. P., and Andersson, A. J.: Coral reefs will transition to net dissolving before end of century, Science, 359, 908-911, https://doi.org/10.1126/science.aao1118, 2018.
Ferguson, A. J. and Eyre, B. D.: Interaction of benthic microalgae and macrofauna in the control of benthic metabolism, nutrient fluxes and denitrification in a shallow sub-tropical coastal embayment (western Moreton Bay, Australia), Biogeochemistry, 112, 423-440, https://doi.org/10.1007/s10533-012-9736-x, 2013.

Ferguson, A. J., Eyre, B. D., and Gay, J. M.: Organic matter and benthic metabolism in euphotic sediments along shallow subtropical estuaries, northern New South Wales, Australia, Aquat. Microb. Ecol., 33, 137-154, https://doi.org/10.3354/ame033137, 2003.

Ferguson, A. J., Eyre, B. D., and Gay, J. M.: Benthic nutrient fluxes in euphotic sediments along shallow sub-tropical estuaries, northern New South Wales, Australia, Aquat. Microb. Ecol., 37, 219-235, https://doi.org/10.3354/ame037219, 2004.

Fichot, C. G. and Benner, R.: The fate of terrigenous dissolved organic carbon in a river-influenced ocean margin, Global Biogeochem. Cy., 28, 300-318, https://doi.org/10.1002/2013gb004670, 2014.

Fischer, E. M. and Knutti, R.: Anthropogenic contribution to global occurrence of heavy-precipitation and hightemperature extremes, Nat. Clim. Change, 5, 560-564, https://doi.org/10.1038/nclimate2617, 2015.

Frankignoulle, M., Abril, G., Borges, A., Bourge, I., Canon, C., Delille, B., Libert, E., and Théate, J.-M.: Carbon dioxide emission from European estuaries, Science, 282, 434-436, https://doi.org/10.1126/science.282.5388.434, 1998.

Gattuso, J.-P., Gentili, B., Antoine, D., and Doxaran, D.: Global distribution of photosynthetically available radiation on the seafloor, Earth Syst. Sci. Data, 12, 1697-1709, https://doi.org/10.5194/essd-12-1697-2020, 2020.

Geider, R. J.: Light and temperature dependence of the carbon to chlorophyll a ratio in microalgae and cyanobacteria: implications for physiology and growth of phytoplankton, New Phytol., 106, 1-34, https://doi.org/10.1111/j.1469-8137.1987.tb04788.x, 1987.

Greene, R. M., Geider, R. J., Kolber, Z., and Falkowski, P. G.: Ironinduced changes in light harvesting and photochemical energy conversion processes in eukaryotic marine algae, Plant Physiol, 100, 565-575, https://doi.org/10.1104/pp.100.2.565, 1992.

Hallett, C. S., Hobday, A. J., Tweedley, J. R., Thompson, P. A., McMahon, K., and Valesini, F. J.: Observed and predicted impacts of climate change on the estuaries of south-western Australia, a Mediterranean climate region, Reg. Environ. Change, 18, 1357-1373, 2018.

Hansell, D. A., Carlson, C. A., Repeta, D. J., and Schlitzer, R.: Dissolved organic matter in the ocean: A controversy stimulates new insights, Oceanography, 22, 202-211, https://doi.org/10.5670/oceanog.2009.109, 2009.

Hardison, A. K., Canuel, E. A., Anderson, I. C., Tobias, C. R., Veuger, B., and Waters, M. N.: Microphytobenthos and benthic macroalgae determine sediment organic matter composition in shallow photic sediments, Biogeosciences, 10, 5571-5588, https://doi.org/10.5194/bg-10-5571-2013, 2013.

Hedges, J. I.: Organic matter in sea water, Nature, 330, 205-206, https://doi.org/10.1038/330205a0, 1987.

Heip, C. H. R., Goosen, N. K., Herman, P. M. J., Kromkamp, J., Middelburg, J. J., and Soetaert, K.: Production and consumption of biological particles in temperate tidal estuaries, Oceanogr. 
Mar. Biol. Ann. Rev., 33, 1-149, in: Oceanography and Marine Biology: An Annual Review, Aberdeen University Press/Allen \& Unwin, London, 1995.

Herrig, R. and Falkowski, P. G.: Nitrogen limitation in Isochrysis Galbana (Haptophyceae). I. Photosynthetic energy convesion and growth efficiencies J. Phycol., 25, 462-471, https://doi.org/10.1111/j.1529-8817.1989.tb00251.x, 1989.

Hopkinson, C. S.: Shallow-water benthic and pelagic metabolism, Mar. Biol., 87, 19-32, https://doi.org/10.1007/BF00397002, 1985.

IPCC: Special Report on the Ocean and Cryosphere in a Changing Climate, edited by: Pörtner, D. C. R. H.-O., Masson-Delmotte, V., Zhai, P., Tignor, M., Poloczanska, E., Mintenbeck, K., Alegría, A., Nicolai, M., Okem, A., Petzold, J., Rama, B., and Weyer, N. M., 2019.

Jørgensen, B. B.: Material flux in the sediment, in: Eutrophication in Coastal Marine Ecosystems, edited by: Jørgensen, B. B. and Richardson, K., Coastal and Estuarine Studies, 115-135, 1996.

Kana, T. M., Geider, R. J., and Critchley, C.: Regulation of photosynthetic pigments in micro-algae by multiple environmental factors: a dynamic balance hypothesis, New Phytol., 137, 629638, https://doi.org/10.1046/j.1469-8137.1997.00857.x, 1997.

Kirchman, D. and Rich, J.: Regulation of bacterial growth rates by dissolved organic carbon and temperature in the equatorial Pacific Ocean, Microb. Ecol., 33, 11-20, https://doi.org/10.1007/s002489900003, 1997.

Krause-Jensen, D. and Duarte, C. M.: Substantial role of macroalgae in marine carbon sequestration, Nat. Geosci., 9, 737-742, https://doi.org/10.1038/ngeo2790, 2016.

Lantz, C. A., Schulz, K. G., Stoltenberg, L., and Eyre, B. D.: The short-term combined effects of temperature and organic matter enrichment on permeable coral reef carbonate sediment metabolism and dissolution, Biogeosciences, 14, 5377-5391, https://doi.org/10.5194/bg-14-5377-2017, 2017.

Lewis, D. and McConchie, D.: Practical Sedimentology, Chapman and Hall, New York, NY, USA, https://doi.org/10.1007/978-14615-2634-6, 1994.

Li, G., Cheng, L., Zhu, J., Trenberth, K. E., Mann, M. E., and Abraham, J. P.: Increasing ocean stratification over the past half-century, Nat. Clim. Change, 10, 1116-1123, https://doi.org/10.1038/s41558-020-00918-2, 2020.

Liu, X., Li, Y., Wu, Y., Huang, B., Dai, M., Fu, F., Hutchins, D. A., and Gao, K.: Effects of elevated $\mathrm{CO}_{2}$ on phytoplankton during a mesocosm experiment in the southern eutrophicated coastal water of China, Sci. Rep.-UK, 7, 6868, https://doi.org/10.1038/s41598-017-07195-8, 2017.

Lønborg, C., Álvarez-Salgado, X. A., Letscher, R. T., and Hansell, D. A.: Large Stimulation of Recalcitrant Dissolved Organic Carbon Degradation by Increasing Ocean Temperatures, Front. Mar. Sci., 4, 436, https://doi.org/10.3389/fmars.2017.00436, 2018.

López-Urrutia, A. and Morán, X. A. G.: Resource limitation of bacterial production distorts the temperature dependence of oceanic carbon cycling, Ecology, 88, 817-822, https://doi.org/10.1890/06-1641, 2007.

Luczak, C., Janquin, M.-A., and Kupka, A.: Simple standard procedure for the routine determination of organic matter in marine sediment, Hydrobiologia, 345, 87-94, https://doi.org/10.1023/A:1002902626798, 1997.
MacIntyre, H. L., Geider, R. J., and Miller, D. C.: Microphytobenthos: the ecological role of the "secret garden" of unvegetated, shallow-water marine habitats. I. Distribution, abundance and primary production, Estuaries, 19, 186-201, https://doi.org/10.2307/1352224, 1996.

Maher, D. T. and Eyre, B. D.: Benthic fluxes of dissolved organic carbon in three temperate Australian estuaries: Implications for global estimates of benthic DOC fluxes, J. Geophys. Res.Biogeo., 115, G04039, https://doi.org/10.1029/2010jg001433, 2010.

Malone, T. C. and Conley, D. J.: Trends in Nutrient Loading and Eutrophication: A Comparison of the Chesapeake Bay and the Hudson River Estuarine Systems, in: Northeast Shelf Ecosystem: Assessment, Sustainability, and Management, edited by: Sherman, K., Jaworski, N. A., and Smayda, T. J., Blackwell Science Ltd, 327-349, 1996.

Mathworks: MATLAB The Mathworks, Inc., Natick, Massachusetts, United States, 2011.

Mehrbach, C., Culberson, C. H., Hawley, J. E., and Pytkowicx, R. M.: Measurement of the Apparent Dissociation Constants of Carbonic Acid in Seawater at Atmospheric Pressure, Limnol. Oceanogr., 18, 897-907, https://doi.org/10.4319/lo.1973.18.6.0897, 1973.

Morak, S., Hegerl, G. C., and Christidis, N.: Detectable Changes in the Frequency of Temperature Extremes, J. Climate, 26, 15611574, https://doi.org/10.1175/jcli-d-11-00678.1, 2013.

Moran, M. A. and Hodson, R. E.: Bacterial production on humic and nonhumic components of dissolved organic carbon, Limnol. Oceanogr., 35, 1744-1756, https://doi.org/10.4319/lo.1990.35.8.1744, 1990.

Morán, X. A. G., Ducklow, H. W., and Erickson, M.: Single-cell physiological structure and growth rates of heterotrophic bacteria in a temperate estuary (Waquoit Bay, Massachusetts), Limnol. Oceanogr., 56, 37-48, https://doi.org/10.4319/lo.2011.56.1.0037, 2011.

Mori, T., Binder, B., and Johnson, C. H.: Circadian gating of cell division in cyanobacteria growing with average doubling times of less than 24 hours, P. Natl. Acad. Sci. USA, 93, 10183, https://doi.org/10.1073/pnas.93.19.10183, 1996.

Novak, T., Godrijan, J., Pfannkuchen, D. M., Djakovac, T., Mlakar, M., Baricevic, A., Tanković, M. S., and Gašparović, B.: Enhanced dissolved lipid production as a response to the sea surface warming, J. Mar. Syst., 180, 289-298, https://doi.org/10.1016/j.jmarsys.2018.01.006, 2018.

Oakes, J. M., Bautista, M. D., Maher, D., Jones, W. B., and Eyre, B. D.: Carbon self-utilization may assist Caulerpa taxifolia invasion, Limnol. Oceanogr., 56, 1824-1831, https://doi.org/10.4319/lo.2011.56.5.1824, 2011.

Oakes, J. M., Eyre, B. D., Middelburg, J. J., and Boschker, H. T. S.: Composition, production, and loss of carbohydrates in subtropical shallow subtidal sandy sediments: Rapid processing and long-term retention revealed by ${ }^{13}$ C-labeling, Limnol. Oceanogr., 55, 2126-2138, https://doi.org/10.4319/lo.2010.55.5.2126, 2010.

Oakes, J. M., Eyre, B. D., and Middelburg, J. J.: Transformation and fate of microphytobenthos carbon in subtropical shallow subtidal sands: A ${ }^{13}$ C-labeling study, Limnol. Oceanogr., 57, 1846-1856, https://doi.org/10.4319/lo.2012.57.6.1846, 2012. 
Oakes, J. M. and Eyre, B. D.: Transformation and fate of microphytobenthos carbon in subtropical, intertidal sediments: potential for long-term carbon retention revealed by ${ }^{13} \mathrm{C}$-labeling, Biogeosciences, 11, 1927-1940, https://doi.org/10.5194/bg-111927-2014, 2014.

Opsahl, S. and Benner, R.: Distribution and cycling of terrigenous dissolved organic matter in the ocean, Nature, 386, 480-482, https://doi.org/10.1038/386480a0, 1997.

Patching, J. and Rose, A.: Chapter II The Effects and Control of Temperature, in: Methods in microbiology, Elsevier, London, New York, 23-38, 1970.

Pierrot, D., Lewis, E., and Wallace, D. W. R.: MS Excel program developed for $\mathrm{CO}_{2}$ system calculations: ORNL/CDIAC-105a, Carbon Dioxide Information Analysis Center Oak Ridge National Laboratory, U.S. Department of Energy, Oak Ridge, Tennessee, 2006.

Raymond, P. A. and Bauer, J. E.: Bacterial consumption of DOC during transport through a temperate estuary, Aquat. Microb. Ecol., 22, 1-12, https://doi.org/10.3354/ame022001, 2000.

Riekenberg, P. M., Oakes, J. M., and Eyre, B. D.: Short-term fate of intertidal microphytobenthos carbon under enhanced nutrient availability: a ${ }^{13} \mathrm{C}$ pulse-chase experiment, Biogeosciences, 15 , 2873-2889, https://doi.org/10.5194/bg-15-2873-2018, 2018.

Rost, B., Zondervan, I., and Wolf-Gladrow, D.: Sensitivity of phytoplankton to future changes in ocean carbonate chemistry: Current knowledge, contradictions and research directions, Mar. Ecol.Prog. Ser., 373, 227-237, https://doi.org/10.3354/meps07776, 2008.

Sandberg, J., Andersson, A., Johansson, S., and Wikner, J.: Pelagic food web structure and carbon budget in the northern Baltic Sea: potential importance of terrigenous carbon, Mar. Ecol.-Prog. Ser., 268, 13-29, 2004.

Schulz, K. G., Bach, L. T., Bellerby, R. G. J., Bermúdez, R., Büdenbender, J., Boxhammer, T., Czerny, J., Engel, A., Ludwig, A., Meyerhöfer, M., Larsen, A., Paul, A. J., Sswat, M., and Riebesell, U.: Phytoplankton Blooms at Increasing Levels of Atmospheric Carbon Dioxide: Experimental Evidence for Negative Effects on Prymnesiophytes and Positive on Small Picoeukaryotes, Front. Mar. Sci., 4, 64, https://doi.org/10.3389/fmars.2017.00064, 2017.

Simone, M., Schulz, K., Oakes, J., and Eyre, B.: Oxygen and carbon fluxes from shallow unvegetated sediments in the Clarence Estuary, NSW, Australia under warming and ocean acidification conditions, PANGAEA, https://doi.org/10.1594/PANGAEA.924460, 2020.

Sett, S., Schulz, K. G., Bach, L. T., and Riebesell, U.: Shift towards larger diatoms in a natural phytoplankton assemblage under combined high- $\mathrm{CO}_{2}$ and warming conditions, J. Plankton Res., 40, 391-406, https://doi.org/10.1093/plankt/fby018, 2018.

Siegenthaler, U. and Sarmiento, J. L.: Atmospheric carbon dioxide and the ocean, Nature, 365, 119-125, https://doi.org/10.1038/365119a0, 1993.

Smith, S. and Hollibaugh, J.: Coastal metabolism and the oceanic organic carbon balance, Rev. Geophys., 31, 75-89, https://doi.org/10.1029/92RG02584, 1993.

Taucher, J., Schulz, K. G., Dittmar, T., Sommer, U., Oschlies, A., and Riebesell, U.: Enhanced carbon overconsumption in response to increasing temperatures during a mesocosm experi- ment, Biogeosciences, 9, 3531-3545, https://doi.org/10.5194/bg9-3531-2012, 2012.

Thomas, M. K., Kremer, C. T., Klausmeier, C. A., and Litchman, E.: A global pattern of thermal adaptation in marine phytoplankton, Science, 338, 1085-1088, https://doi.org/10.1126/science.1224836, 2012.

Trnovsky, D., Stoltenberg, L., Cyronak, T., and Eyre, B. D.: Antagonistic Effects of Ocean Acidification and Rising Sea Surface Temperature on the Dissolution of Coral Reef Carbonate Sediments, Front. Mar. Sci., 3, 211, https://doi.org/10.3389/fmars.2016.00211, 2016.

Underwood, G. and Kromkamp, J.: Primary Production by Phytoplankton and Microphytobenthos in Estuaries in: Advances in Ecological Research - estuaries, edited by: Nedwell, D. B. and Raffaelli, D. G., Academic Press, San Diego, CA, 93-153, 1999.

Uppström, L. R.: The boron/chlorinity ratio of deep-sea water from the Pacific Ocean, Deep Sea Research and Oceanographic Abstracts, 161-162, 1974.

Valiela, I.: Marine ecological processes, 2nd ed., Springer Verlag, New York, NY, 1995.

Vázquez-Domínguez, E., Vaqué, D., and Gasol, J. M.: Temperature effects on the heterotrophic bacteria, heterotrophic nanoflagellates, and microbial top predators of the NW Mediterranean, Aquat. Microb. Ecol., 67, 107-121, https://doi.org/10.3354/ame01583, 2012.

Vopel, K., Del-Rio, C., and Pilditch, C. A.: Effects of $\mathrm{CO}_{2}$ enrichment on benthic primary production and inorganic nitrogen fluxes in two coastal sediments, Sci. Rep.-UK, 8, 1035, https://doi.org/10.1038/s41598-017-19051-w, 2018.

Wagner, S., Schubotz, F., Kaiser, K., Hallmann, C., Waska, H., Rossel, P. E., Hansman, R., Elvert, M., Middelburg, J. J., Engel, A., Blattmann, T. M., Catalá, T. S., Lennartz, S. T., Gomez-Saez, G. V., Pantoja-Gutiérrez, S., Bao, R., and Galy, V.: Soothsaying DOM: A Current Perspective on the Future of Oceanic Dissolved Organic Carbon, Front. Mar. Sci., 7, 341, https://doi.org/10.3389/fmars.2020.00341, 2020.

Webb, A. P. and Eyre, B. D.: The effects of two benthic chamber stirring systems on the diffusive boundary layer, oxygen flux, and passive flow through model macrofauna burrows, Estuar. Coasts, 27, 352-361, https://doi.org/10.1007/BF02803391, 2004.

Wohlers, J., Engel, A., Zöllner, E., Breithaupt, P., Jürgens, K., Hoppe, H.-G., Sommer, U., and Riebesell, U.: Changes in biogenic carbon flow in response to sea surface warming, P. Natl. Acad. Sci.-USA, 106, 7067, https://doi.org/10.1073/pnas.0812743106, 2009.

Yang, Z., Zhang, L., Zhu, X., Wang, J., and Montagnes, D. J.: An evidence-based framework for predicting the impact of differing autotroph-heterotroph thermal sensitivities on consumer-prey dynamics, ISME J., 10, 1767, https://doi.org/10.1038/ismej.2015.225, 2016.

Yap, H. T., Montebon, A. R. F., and Dizon, R. M.: Energy flow and seasonality in a tropical coral reef flat, Mar. Ecol.-Prog. Ser., 103, 35-43, https://doi.org/10.3354/meps103035, 1994. 